\title{
Merkel Cell-Driven BDNF Signaling Specifies SAI Neuron Molecular and Electrophysiological Phenotypes
}

\author{
Erin G. Reed-Geaghan, ${ }^{1}$ Margaret C. Wright, ${ }^{2}$ Lauren A. See, ${ }^{1}$ Peter C. Adelman, ${ }^{3}$ Kuan Hsien Lee, ${ }^{3}$ H. Richard Koerber, ${ }^{3}$ \\ and ${ }^{-S t e p h e n ~ M . ~ M a r i c i c h ~}{ }^{4}$ \\ ${ }^{1}$ Department of Pediatrics, Case Western Reserve University, Cleveland, Ohio 44106, ${ }^{2}$ Center for Neurosciences, and ${ }^{3}$ Department of Neurobiology, \\ University of Pittsburgh, Pittsburgh, Pennsylvania 15260, and ${ }^{4}$ Department of Pediatrics, Richard King Mellon Institute for Pediatric Research, University \\ of Pittsburgh and Children's Hospital of Pittsburgh of UPMC, Pittsburgh, Pennsylvania 15224
}

The extent to which the skin instructs peripheral somatosensory neuron maturation is unknown. We studied this question in Merkel cell-neurite complexes, where slowly adapting type I (SAI) neurons innervate skin-derived Merkel cells. Transgenic mice lacking Merkel cells had normal dorsal root ganglion (DRG) neuron numbers, but fewer DRG neurons expressed the SAI markers TrkB, TrkC, and Ret. Merkel cell ablation also decreased downstream TrkB signaling in DRGs, and altered the expression of genes associated with SAI development and function. Skin- and Merkel cell-specific deletion of Bdnf during embryogenesis, but not postnatal Bdnf deletion or $N t f 3$ deletion, reproduced these results. Furthermore, prototypical SAI electrophysiological signatures were absent from skin regions where $B d n f$ was deleted in embryonic Merkel cells. We conclude that BDNF produced by Merkel cells during a precise embryonic period guides SAI neuron development, providing the first direct evidence that the skin instructs sensory neuron molecular and functional maturation.

Key words: BDNF; mechanoreceptor; Merkel cell; SAI; TrkB

Significance Statement

Peripheral sensory neurons show incredible phenotypic and functional diversity that is initiated early by cell-autonomous and local environmental factors found within the DRG. However, the contribution of target tissues to subsequent sensory neuron development remains unknown. We show that Merkel cells are required for the molecular and functional maturation of the SAI neurons that innervate them. We also show that this process is controlled by BDNF signaling. These findings provide new insights into the regulation of somatosensory neuron development and reveal a novel way in which Merkel cells participate in mechanosensation.

\section{Introduction}

Peripheral sensory neurons detect a wide variety of pain, temperature, proprioceptive, and touch stimuli. This functional heterogeneity is reflected in their phenotypic diversity in terms of size, projection patterns, molecular marker expression, and electrophysiological properties. Intrinsic transcription factor expression

\footnotetext{
Received Oct. 15, 2015; revised March 5, 2016; accepted March 7, 2016.

Author contributions: E.G.R.-G., P.C.A., H.R.K., and S.M.M. designed research; E.G.R.-G., M.C.W., L.A.S., P.C.A., and K.H.L. performed research; E.G.R.-G., M.C.W., and P.C.A. analyzed data; E.G.R.-G., P.C.A., H.R.K., and S.M.M. wrote the paper.

This work was supported by National Institutes of Health Grants F32-NS-074758 (E.G.R.-G.), R01-NS-023725 (H.R.K.), and R01-AR-059114 (S.M.M.); and by the Richard King Mellon Foundation for Pediatric Research (S.M.M.). We thank members of the Maricich laboratory and Dr. Sharyl Fyffe-Maricich for their thoughtful discussions and input; Dr. Timothy Sanders at Children's Hospital of Pittsburgh and his laboratory for help with confocal microscopy; and Dr. Gary Landreth at Case Western Reserve University and his laboratory for laboratory space.

The authors declare no competing financial interests.

Correspondence should be addressed to Stephen M. Maricich, Rangos Research Building, Room 8129, One Children's Hospital Drive, Pittsburgh, PA 15224. E-mail: stephen.maricich@chp.edu.

DOI:10.1523/JNEUROSCI.3781-15.2016

Copyright $\odot 2016$ the authors $\quad 0270-6474 / 16 / 364362-15 \$ 15.00 / 0$
}

initially separates newly born sensory neurons into different neuronal subtypes as they settle into nascent dorsal root ganglia (DRGs; Marmigère and Ernfors, 2007; Reed-Geaghan and Maricich, 2011). However, the factors that direct DRG neuron differentiation and maturation following initial cell fate specification, and the sources of these factors are poorly understood.

Neurotrophins (NTs) are a group of related molecules that includes nerve growth factor, brain-derived neurotrophic factor (BDNF), NT3, and glial cell line-derived neurotrophic factor (GDNF). These neurotrophins promote DRG neuron survival by acting through their cognate receptors TrkA, TrkB, TrkC, and Ret, respectively. Neurotrophins are also implicated in maintenance of neuronal identity, maintenance of neuronal subtypespecific gene expression, and proper targeting/morphology of central and peripheral projections (Marmigère and Carroll, 2014). However, given the limitations of overexpression and constitutive knock-out studies, how target tissue-derived neurotrophins might influence sensory neuron maturation remains an unanswered question. 
The Merkel cell-neurite complex, composed of slowly adapting type I (SAI) cutaneous sensory afferents and skin-derived Merkel cells, is a tractable model system in which to study this question. Merkel cells are not required for SAI targeting to the skin, but SAI afferent morphology, electrophysiological responses, and texture discrimination tasks are all altered in the absence of Merkel cells (Maricich et al., 2009, 2012; Maksimovic et al., 2014). However, these data were generated in transgenic mouse models that lacked Merkel cells or Merkel cell function throughout life, raising the possibility that developmental interactions between Merkel cells and SAI neurons might account for some or all of the observed phenotypes. This is an important consideration because the cell-autonomous and non-cellautonomous mechanisms that control SAI molecular phenotype, peripheral projection morphology, and electrophysiological function are unknown. Importantly, multiple lines of evidence suggest that SAI neurons respond to BDNF and NT3 signaling, presumably through the expression of TrkB and TrkC (Airaksinen et al., 1996; Albers et al., 1996; Fundin et al., 1997; Carroll et al., 1998; LeMaster et al., 1999; Cronk et al., 2002; Szeder et al., 2003; Krimm et al., 2004). These observations raise the possibility that Merkel cell-derived neurotrophins might play a role in directing SAI neuron maturation.

Here, we investigated whether Merkel cells, and specifically Merkel cell-derived neurotrophins, participate in SAI molecular and electrophysiological phenotype acquisition. We show that Merkel cell deletion alters the percentage of DRG neurons that express TrkB, TrkC, and Ret without changing DRG neuron numbers. These phenotypes are recapitulated by conditional $B d n f$ deletion throughout embryonic skin cells or, specifically, in Merkel cells. Moreover, SAI electrophysiological responses are altered following embryonic $B d n f$ deletion, specifically in Merkel cells. These findings identify a novel role for Merkel cells in SAI neuron maturation.

\section{Materials and Methods}

Mice. K14 ${ }^{\text {Cre }}$ (Dassule et al., 2000; strain \#004782, The Jackson Laboratory), Atoh1 ${ }^{\text {CreER-T2 }}$ (Fujiyama et al., 2009), Atoh1 ${ }^{\text {flox }}$ (Shroyer et al., 2007; strain \#008681, The Jackson Laboratory), Atoh $1^{\text {LacZ }}$ (Ben-Arie et al., 2000; strain \#005970, The Jackson Laboratory), Bdnflox (Rios et al., 2001; strain \#004339, The Jackson Laboratory), Ntf $3^{\text {flox }}$ (Bates et al., 1999; strain \#003541, The Jackson Laboratory), and ROSA ${ }^{\text {tdTomato }}$ (Madisen et al., 2010; strain \#00007914, The Jackson Laboratory) were maintained in accordance with institutional animal care and use committee guidelines at Case Western Reserve University and Children's Hospital of Pittsburgh of UPMC. For embryonic ages, the plug date was designated as embryonic day 0.5 (E0.5).

Tamoxifen administration. Tamoxifen (Sigma-Aldrich) was dissolved 9:1 in a corn oil/ethanol solution at a 5\% concentration. Pregnant dams were given a single dose of $250 \mathrm{mg} / \mathrm{kg}$ by oral gavage. Lactating females were given one dose of $250 \mathrm{mg} / \mathrm{kg}$ by oral gavage on 3 consecutive days.

Tissue processing and sectioning. Adult mice [postnatal day 21 (>P21)] were killed by cervical dislocation. Embryos were dissected from pregnant dams into cold PBS, and tails were collected from each embryo for genotyping. Embryonic and young mice $(<\mathrm{P} 21)$ were decapitated before tissue dissection. Spinal columns were fixed in $4 \%$ paraformaldehyde (PFA) overnight at $4^{\circ} \mathrm{C}$, washed in PBS, and cryopreserved in $30 \%$ sucrose/PBS overnight at $4^{\circ} \mathrm{C}$. Spinal columns from P21 mice were decalcified in $0.5 \mathrm{~m}$ EDTA for $5 \mathrm{~d}$ following fixation prior to cryoprotection. Skin for immunohistochemistry was fixed in $4 \%$ PFA for 30 min on ice, washed in PBS, and visualized in whole mount or cryopreserved in $30 \%$ sucrose/PBS. Cryopreserved tissue was embedded in OCT (ThermoFisher Scientific), serially sectioned on a Leica $1950 \mathrm{M}$ cryostat at $10 \mu \mathrm{m}$ (DRGs) or $25 \mu \mathrm{m}$ (skin), and collected on Superfrost Plus slides (ThermoFisher Scientific). Slides were dried at room temperature overnight.
Immunohistochemistry. Slides were vacuum dried, rehydrated in PBS, subjected to heat-induced epitope retrieval, washed three times in PBS, and blocked with $5 \%$ normal donkey serum (NDS) in $0.3 \%$ PBS-T (PBS with Triton X-100). Heat-induced epitope retrieval consisted of incubating slides in sub-boiling $10 \mathrm{~mm}$ citrate buffer for $10 \mathrm{~min}$, followed by 30 min at room temperature. Slides were incubated overnight at $4^{\circ} \mathrm{C}$ in blocking solution containing primary antibodies. Slides were washed in PBS and incubated with the appropriate secondary antibodies diluted in blocking solution for $30 \mathrm{~min}$ at room temperature. Slides were washed, counterstained with DAPI ( $4^{\prime}, 6^{\prime}$-diamidino-2-phenylindole dihydrochloride; 1:1000; ThermoFisher Scientific) to visualize nuclei, and mounted in Invitrogen Prolong Gold (ThermoFisher Scientific). The primary antibodies used were mouse anti-Islet1/2 (1:50; catalog \#39.4D5, Developmental Studies Hybridoma Bank), rabbit anti-NF200 (1:1000; N4142, Sigma-Aldrich), goat anti-TrkB (1:200; AF1494, R\&D Systems), goat anti-TrkC [AF1404 (1:100) and BAF1404 (1:20), R\&D Systems], rabbit anti-Ret (1:50; catalog \#18121, Immuno-Biological Laboratories), rabbit anti-parvalbumin (PV; 1:1000; PV25, Swant), rabbit anti-CGRP (1:1000; T-4032, Peninsula Laboratories), rabbit anti-phospho-SMAD1/ 5/8 (1:250; catalog 9511, Cell Signaling Technology), goat anti-TBX3 (1:100; sc-31656, Santa Cruz Biotechnology), rat anti-Keratin8 (1:20, TROMA-1, Developmental Studies Hybridoma Bank), guinea pig antiAsic1 (1:250; Alomone Labs), rabbit anti- $\delta$ opioid receptor (DOR; 1:500; Alomone Labs), and rabbit anti- $\gamma \mathrm{ENaC}$ (1:500; StressMarq Biosciences). Secondary antibodies conjugated to various fluorophores (Jackson Immunochemicals) were all used at 1:250 except streptavidin, which was used at a 1:2000 dilution.

Whole-mount immunostaining was performed by modifying previously published protocols ( $\mathrm{Li}$ et al., 2011) on pelts of hairy skin. Fixed skin was dissected into small pieces, and the underlying adipose tissue was removed then washed for $5-8 \mathrm{~h}$ in $0.3 \%$ PBS-T. Tissue was incubated with primary antibodies for $4 \mathrm{~d}$, washed for $5-8 \mathrm{~h}$ in $0.3 \% \mathrm{PBS}-\mathrm{T}$, then incubated with secondary antibodies for $2 \mathrm{~d}$, all at room temperature. Antibodies were diluted in 20\% dimethylsulfoxide/5\% NDS/0.3\% PBS-T.

Cell counts. Neuronal counts and imaging were performed on a Leica DM 5500B fluorescent microscope. Neurons were counted using a dual red/green fluorescent filter. All neurons expressing a given marker with identifiable nuclei were counted. Islet $1 / 2^{+}$neurons were counted in every third section throughout the entire dorsal root ganglion, and the sum was multiplied by three for the total neuron number. Merkel cell counts in whole-mount skin preparations were performed as previously described (Wright et al., 2015). Briefly, all $\mathrm{K}^{+}{ }^{+}$cells in each touch dome within a $0.5 \mathrm{~cm}^{2}$ of back and belly skin were counted.

RNA extraction, reverse transcription, and quantitative PCR. Thoracic DRGs were dissected from P0 and P21 mice in cold DEPC-treated PBS and snap frozen on dry ice. Tissue was homogenized using a syringe with a 28 ga needle followed by $10 \mathrm{~s}$ of sonication. RNA was isolated using the RNeasy Mini Kit (Qiagen) according to the manufacturer instructions, and analyzed for concentration and purity by a NanoDrop 2000 spectrophotometer (ThermoFisher Scientific). Equal amounts of RNA were reverse transcribed using a QuantiTect Reverse Transcription kit (Qiagen) per the manufacturer instructions. Dilutions of cDNA were made and used for quantitative PCR (qPCR) using Applied Biosystems StepOne Plus software (ThermoFisher Scientific) with Applied Biosystems FAM (5-carboxylfluorescein)-labeled TaqMan assays (ThermoFisher Scientific) for Asic1 (Mm01305997_m1), Asic2 (Mm00475691_m1), Asic3 (Mm00805460_m1), Calca (Mm00801463_g1), Cux2 (Mm00500377_m1), Egr1 (Mm00656724_m1), Fos (Mm00487425_m1), Kcnal (Mm00439977_s1), MafA (Mm00845206_s1), Nr4a1 (Mm01300401_m1), Oprd1 (Mm00443063_ m1), Pvalb (Mm00443100_m1), Runx1 (Mm0121344_m1), Runx3 (Mm00490666_m1), Sall1 (Mm00491266_m1), Scnn1b (Mm00441215_ m1), Scnn1 g (Mm00441228_m1), Shox2 (Mm00443183_m1), Slc17a6 (Mm00499876_m1), Slc17a7 (Mm00812886_m1), Slc17a8 (Mm00805413_ m1), Tbx3 (Mm01195726_m1), TrpC1 (Mm00441975_m1), and TrpV4 (Mm00499025_m1). Gene expression analysis was performed using the comparative $\mathrm{C}_{\mathrm{t}}$ method $\left(\Delta \Delta \mathrm{C}_{\mathrm{t}}\right)$, where the threshold cycle for the target genes was normalized to that of the endogenous controls Calca and Pvalb $\left(\Delta \mathrm{C}_{\mathrm{t}}\right)$, and the relative quotient (RQ) was calculated using the equation 

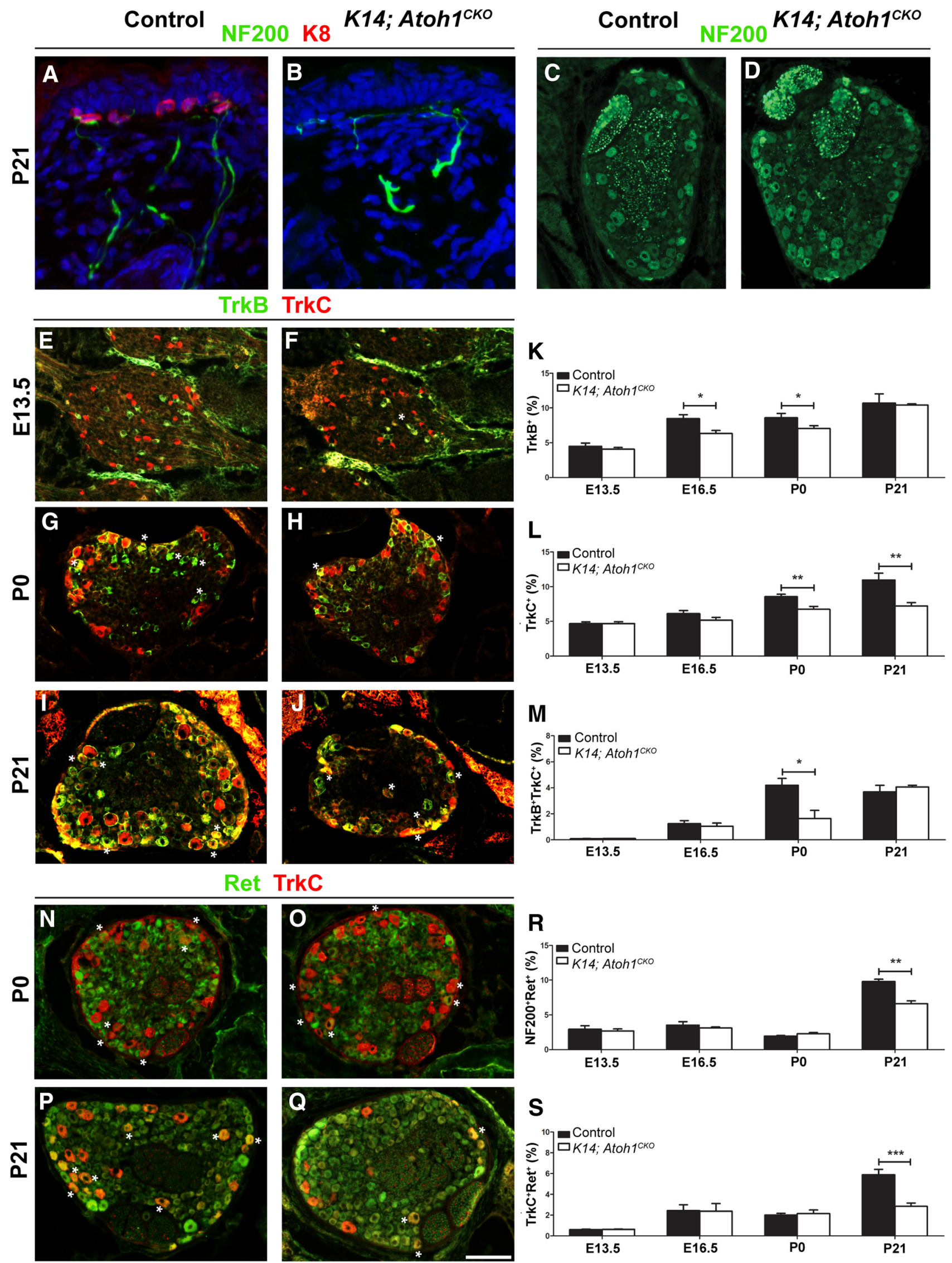

Figure 1. SAI DRG neurons survive following Merkel cell deletion but lose the expression of TrkB, TrkC, and Ret. $A, B$, Immunostaining for K8 and NF200 in the skin of P21 control littermate and K14; Atoh $7^{\mathrm{CKO}}$ mice demonstrates touch dome innervation. C, D, Immunostaining for NF200 in T7 DRG sections from P21 control littermate and K14; Atoh $7^{C K O}$ mice. E-J, N-Q, Immunostaining for TrkB and TrkC $(\boldsymbol{E}-\boldsymbol{J})$ or TrkC and Ret $(\boldsymbol{N}-\mathbf{Q})$ in T7 DRG sections from E13.5, P0 and P21 control littermate, and K14; Atoh $7^{C K O}$ mice. $\boldsymbol{K}-\boldsymbol{M}, \boldsymbol{R}, \mathbf{S}$, Percentages of (Figure legend continues.) 
$2^{-\Delta \Delta \mathrm{Ct}}$, where $\Delta \Delta \mathrm{C}_{\mathrm{t}}=\left(\Delta \mathrm{C}_{\mathrm{t}}\right.$ test sample $-\Delta \mathrm{C}_{\mathrm{t}}$ calibrator sample $)$. All data represent RQ values, while the statistical analyses were performed on $\Delta \mathrm{C}_{\mathrm{t}} \pm \mathrm{SEM}$ values for each target gene, as previously described (Yuan et al., 2006).

Skin-nerve preparations and recordings. Peripheral teased nerve preparations were prepared as previously described (McIlwrath et al., 2007). Briefly, mice were anesthetized with a ketamine $(90 \mathrm{mg} / \mathrm{kg}) /$ xylazine $(10$ $\mathrm{mg} / \mathrm{kg}$ ) mixture and perfused using chilled oxygenated $\left(95 \% \mathrm{O}_{2} / 5 \%\right.$ $\mathrm{CO}_{2}$ ) ACSF (127 mm NaCl, $26 \mathrm{~mm} \mathrm{NaHCO} 3,10 \mathrm{~mm}$ D-glucose, $2.4 \mathrm{~mm}$ $\mathrm{CaCl}_{2}, 1.9 \mathrm{~mm} \mathrm{KCl}, 1.3 \mathrm{~mm} \mathrm{MgSO}$, and $1.2 \mathrm{~mm} \mathrm{KH}_{2} \mathrm{PO}_{4}$ ). The spinal column and right hindlimb were then removed, and placed in a circulating bath of the same oxygenated ACSF. The hairy skin of the hindlimb and hip with connected saphenous nerve was isolated and transferred to a second recording chamber with circulating oxygenated ACSF, where it was heated to $31^{\circ} \mathrm{C}$. The saphenous nerve was pulled into an isolated inner recording chamber, where the epineurium was removed and the nerve was subdivided for recording, as previously described.

Mechanical fields were identified using a paintbrush and localized using von Frey monofilaments. Controlled mechanical forces (square waves) were presented using a force-modulating mechanical stimulator (Aurora Scientific) with a 1-mm-diameter plastic foot. Cells were given $30 \mathrm{~s}$ to recover between stimuli. Peripheral conduction velocity $(\mathrm{CV})$ was calculated using spike latency and the distance between concentric stimulating and recording electrodes. Responses were analyzed off-line (Spike2 software, Cambridge Electronic Design). Somatosensory afferents were first classified by $\mathrm{CV}$ ( $\mathrm{A} \beta$ fibers, $\mathrm{CV} \geq 10$; $\mathrm{A} \delta$ fibers, $\mathrm{CV}<10$ and $\geq 1$; C-fibers, $C V<1$ ); C-fibers and cells with unclear $C V$ s were not analyzed further $(n=70)$. Rapidly adapting (RA) $\mathrm{A} \beta$ - and $\mathrm{A} \delta$-fibers were separated qualitatively based on their response properties (single onset/offset spiking, $n=69$ ), and the $\mathrm{A} \beta$ population was then further subdivided based on the coefficient of variance $(\mathrm{CoV})$ during the last $3 \mathrm{~s}$ of mechanical stimulation [SA1: $\mathrm{CoV},>0.7$; high-threshold mechanoreceptor (HTMR): $\mathrm{CoV},<0.7]$; this classification agrees with previous publications (McIlwrath et al., 2007; Wellnitz et al., 2010).

Statistics. All data are expressed as the mean \pm SEM. Independentsample two-tailed $t$ tests were performed between genotypes at each age for normally distributed data (Excel, Microsoft). The Mann-Whitney $U$ test (Prism, GraphPad Software) was used for nonparametric data.

\section{Results \\ DRG neuron numbers are normal in mice that lack Merkel cells}

To study the role of Merkel cells in SAI neuron development, we used Keratin14 ${ }^{\text {Cre }}$; Atoh1 ${ }^{\text {LacZ/flox }}$ (K14; Atoh1 ${ }^{\text {CKO }}$ ) mice, where epidermal deletion of Atoh1 prevents Merkel cell production (Maricich et al., 2012). Adult K14; Atoh1 ${ }^{C K O}$ mice retain touch dome innervation, have normal numbers of total Islet $1 / 2^{+}$thoracic level 7 (T7) DRG neurons, and have normal numbers of large NF200 ${ }^{+}$T7 DRG neurons at four important stages of SAI neuron development, as follows: before touch dome innervation (E13.5); shortly after Merkel cell innervation (E16.5); when Merkel cell innervation is complete ( $\mathrm{P} 0)$; and when prototypical SAI responses can be recorded (P21; Pasche et al., 1990; Casserly et al., 1994; Koltzenburg et al., 1997; Maricich et al., 2009; Fig. $1 A-D$; Table 1). Total DRG neuron numbers are also normal at the L2 and L4/5 DRG levels in P0 K14; Atoh $1^{\text {CKO }}$ mice (Fig. 2E). These data suggest that SAI neurons survive and innervate touch domes in K14; Atoh ${ }^{C K O}$ mice.

(Figure legend continued.) $\quad$ Islet1/2 ${ }^{+}$T7 DRG neurons that were $\operatorname{TrkB}^{+}(\boldsymbol{K}), \operatorname{TrkC}^{+}(\boldsymbol{L})$, $\operatorname{TrkC}^{+} \operatorname{TrkB}^{+}(\boldsymbol{M}), \mathrm{NF}_{200}{ }^{+} \operatorname{Ret}^{+}(\boldsymbol{R})$, and $\operatorname{TrkC}^{+} \operatorname{Ret}^{+}(\boldsymbol{S})$ in E13.5, E16.5, P0 and P21 control, and $K 14 ;$ Atoh $7^{K K O}$ mice ( $n \geq 3$ mice/genotype/age). In photographs, asterisks indicate doublelabeled cells. In graphs, error bars represent the SEM, and asterisks indicate statistically significant differences between control and K14; Atoh $1^{\mathrm{CKO}}$ mice. ${ }^{*} p<0.05 ;{ }^{* *} p<0.01$; ${ }^{* * *} p<$ 0.001. Scale bar, $100 \mu \mathrm{m}$.
Table 1. Marker expression for T7 DRG neurons in the absence of Merkel cells

\begin{tabular}{|c|c|c|c|c|c|}
\hline$\overline{\text { Protein }}$ & Age & Control & K14; Atoh1 ${ }^{\text {CKO }}$ & $n$ & $\overline{p \text { Value }}$ \\
\hline \multirow[t]{4}{*}{ Islet $1 / 2$} & E13.5 & $5025 \pm 168$ & $5170 \pm 97$ & 23 & 0.45 \\
\hline & E16.5 & $4974 \pm 165$ & $5344 \pm 201$ & 36,32 & 0.16 \\
\hline & PO & $4639 \pm 124$ & $4618 \pm 128$ & 43 & 0.91 \\
\hline & P21 & $5060 \pm 183$ & $5028 \pm 171$ & 26,24 & 0.90 \\
\hline \multirow[t]{4}{*}{ NF200 } & E13.5 & $742 \pm 90$ & $823 \pm 41$ & 4 & 0.44 \\
\hline & E16.5 & $762 \pm 16$ & $793 \pm 42$ & 4 & 0.51 \\
\hline & PO & $719 \pm 22$ & $747 \pm 42$ & 12 & 0.56 \\
\hline & P21 & $1105 \pm 89$ & $1002 \pm 19$ & 3 & 0.32 \\
\hline \multirow[t]{4}{*}{ TrkB } & E13.5 & $4.5 \pm 0.48 \%$ & $4.1 \pm 0.26 \%$ & 3 & 0.49 \\
\hline & E16.5 & $8.5 \pm 0.59 \%$ & $6.3 \pm 0.41 \%$ & 7,6 & 0.02 \\
\hline & Po & $8.6 \pm 0.63 \%$ & $7.0 \pm 0.42 \%$ & 13 & 0.05 \\
\hline & P21 & $10.7 \pm 1.33 \%$ & $10.4 \pm 0.20 \%$ & 3 & 0.83 \\
\hline \multirow[t]{4}{*}{ TrkC } & E13.5 & $4.7 \pm 0.27 \%$ & $4.7 \pm 0.27 \%$ & 12 & 0.95 \\
\hline & E16.5 & $6.1 \pm 0.43 \%$ & $5.2 \pm 0.40 \%$ & 21,18 & 0.12 \\
\hline & Po & $8.6 \pm 0.34 \%$ & $6.7 \pm 0.42 \%$ & 16 & 0.002 \\
\hline & P21 & $11.0 \pm 0.98 \%$ & $7.2 \pm 0.50 \%$ & 12 & 0.003 \\
\hline \multirow[t]{4}{*}{ TrkB/TrkC } & E13.5 & $0.1 \pm 0.01 \%$ & $0.1 \pm 0.01 \%$ & 3 & 0.46 \\
\hline & E16.5 & $1.2 \pm 0.24 \%$ & $1.1 \pm 0.23 \%$ & 7,6 & 0.59 \\
\hline & PO & $4.2 \pm 0.52 \%$ & $1.6 \pm 0.62 \%$ & 6 & 0.01 \\
\hline & P21 & $3.7 \pm 0.51 \%$ & $4.1 \pm 0.14 \%$ & 3 & 0.51 \\
\hline \multirow[t]{4}{*}{ NF200/Ret } & E13.5 & $2.9 \pm 0.52 \%$ & $2.7 \pm 0.30 \%$ & 4 & 0.71 \\
\hline & E16.5 & $3.5 \pm 0.48 \%$ & $3.1 \pm 0.15 \%$ & 4 & 0.45 \\
\hline & $\mathrm{PO}$ & $2.0 \pm 0.07 \%$ & $2.3 \pm 0.19 \%$ & 6 & 0.17 \\
\hline & P21 & $9.8 \pm 0.33 \%$ & $6.6 \pm 0.41 \%$ & 3 & 0.004 \\
\hline \multirow[t]{4}{*}{ TrkC/Ret } & E13.5 & $0.6 \pm 0.05 \%$ & $0.6 \pm 0.03 \%$ & 3 & 0.68 \\
\hline & E16.5 & $2.4 \pm 0.57 \%$ & $2.4 \pm 0.72 \%$ & 4 & 0.97 \\
\hline & Po & $2.0 \pm 0.18 \%$ & $2.2 \pm 0.34 \%$ & 4 & 0.70 \\
\hline & P21 & $5.9 \pm 0.52 \%$ & $2.9 \pm 0.32 \%$ & 6 & 0.0006 \\
\hline \multirow[t]{4}{*}{ PV } & E13.5 & $1.3 \pm 0.15 \%$ & $1.4 \pm 0.12 \%$ & 6 & 0.81 \\
\hline & E16.5 & $2.9 \pm 0.37 \%$ & $2.5 \pm 0.29 \%$ & 10,8 & 0.41 \\
\hline & PO & $2.8 \pm 0.25 \%$ & $2.2 \pm 0.18 \%$ & 6 & 0.10 \\
\hline & P21 & $2.5 \pm 0.21 \%$ & $2.3 \pm 0.42 \%$ & 6 & 0.63 \\
\hline \multirow[t]{4}{*}{$\mathrm{PV} / \mathrm{TrkC}$} & E13.5 & $1.3 \pm 0.15 \%$ & $1.4 \pm 0.12 \%$ & 6 & 0.81 \\
\hline & E16.5 & $2.9 \pm 0.37 \%$ & $2.50 \pm 0.29 \%$ & 10,8 & 0.41 \\
\hline & PO & $2.8 \pm 0.25 \%$ & $2.2 \pm 0.18 \%$ & 6 & 0.10 \\
\hline & P21 & $2.5 \pm 0.21 \%$ & $2.3 \pm 0.42 \%$ & 6 & 0.63 \\
\hline $\mathrm{NF} 200 / \gamma \mathrm{ENaC}$ & P21 & $11.1 \pm 0.17 \%$ & $7.0 \pm 0.37 \%$ & 3 & 0.0006 \\
\hline NF200/ASIC1 & P21 & $12.9 \pm 1.61 \%$ & $12.7 \pm 0.73 \%$ & 3 & 0.88 \\
\hline NF200/DOR & P21 & $13.1 \pm 0.80 \%$ & $11.7 \pm 0.48 \%$ & 3 & 0.20 \\
\hline
\end{tabular}

Values are given as T7 DRG neuron counts and the percentages of total neuron numbers expressing different markers in $K 14 ; A t o h 7^{C K O}$ and control littermate mice, and are reported as the mean $\pm S E M$, unless otherwised indicated.

\section{DRG neuron expression of neurotrophin receptors and transcription factors associated with mechanoreception decreases in K14; Atoh $^{C K O}$ mice}

No one specific marker separates SAI neurons from other DRG neurons. However, BDNF-TrkB signaling plays a role in SAI afferent morphology and function (Ernfors et al., 1994; Minichiello et al., 1995; Fundin et al., 1997; Liebl et al., 1997; Carroll et al., 1998; LeMaster et al., 1999; Liebl et al., 2000; PerezPinera et al., 2008), so we examined TrkB expression. Before touch dome innervation at E13.5, the percentages of TrkB ${ }^{+}$DRG neurons were equivalent in K14; Atoh $1^{C K O}$ mice and control littermates (Fig. 1 E, F,K; Table 1 ). In contrast, at E16.5 and at $\mathrm{P} 0$ the percentages of $\mathrm{TrkB}^{+} \mathrm{DRG}$ neurons were $2.2 \%$ and $1.6 \%$ lower, respectively, in K14; Atoh $1^{\mathrm{CKO}}$ mice versus control littermates (Fig. 1G,H,K; Table 1). The percentages of TrkB ${ }^{+}$DRG neurons were again similar in K14; Atoh $1^{C K O}$ and control littermates at P21 (Fig. 1I-K; Table 1). These data suggest that TrkB protein expression is dynamically regulated in DRG neurons, that TrkB expression in SAI neurons at late embryonic and early postnatal ages requires Merkel cells, and that SAI neurons normally downregulate TrkB protein expression while other neuronal populations upregulate TrkB protein expression at postnatal ages. 


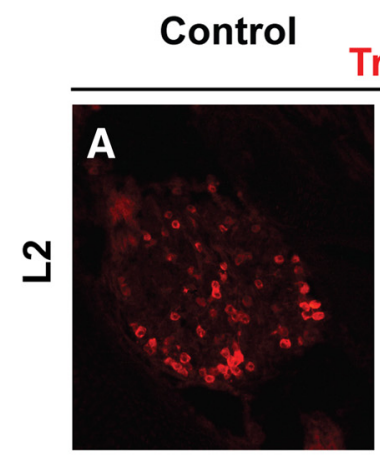

\section{K14; Atoh1 ${ }^{\text {кKо }}$}
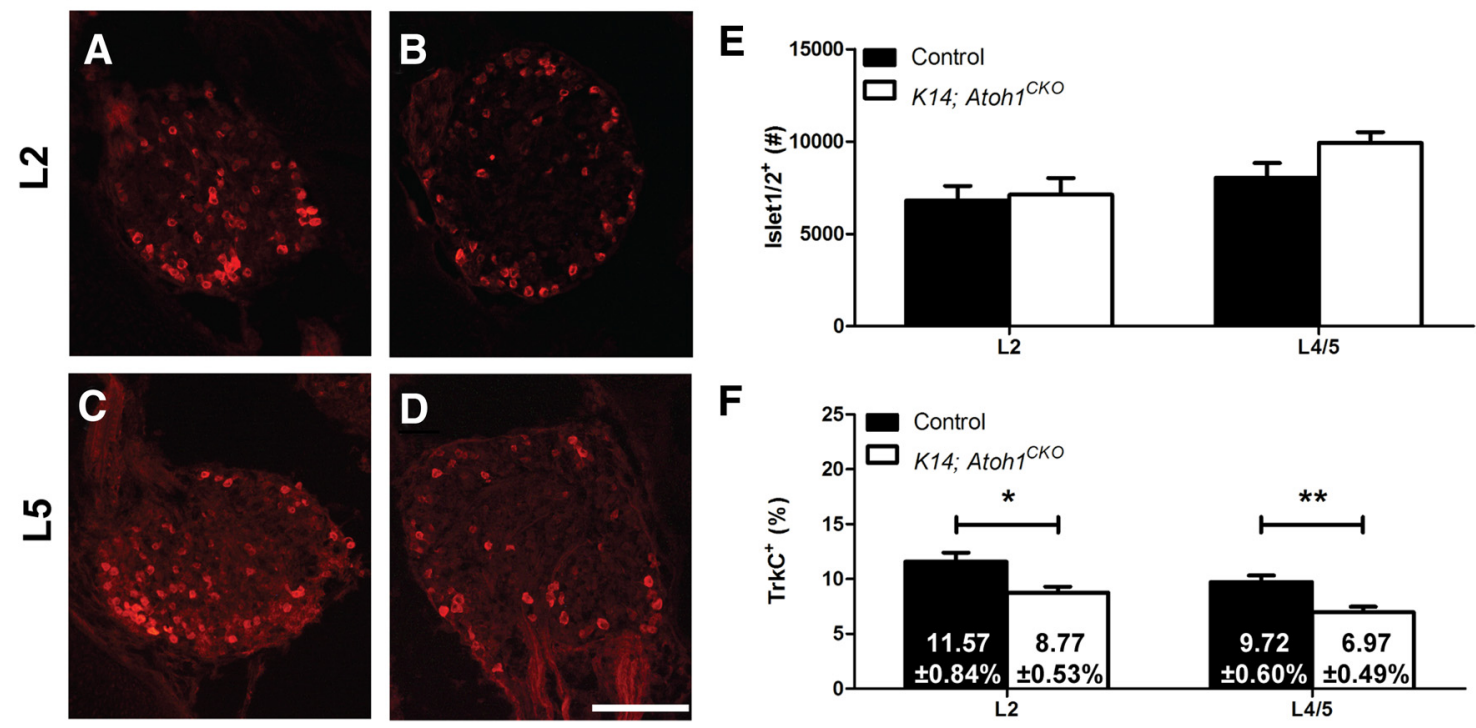

Figure 2. Loss of TrkC expression but not neurons in DRGs of PO K14; Atoh $7^{C K O}$ mice is consistent across spinal levels. A-D, Immunostaining for TrkC in L2 and L4/5 DRG sections from P0 control littermate and K14; Atoh $7^{C K O}$ mice. E, Numbers of Islet $1 / 2^{+}$neurons in PO L2 and L4/5 DRGs from control and K14; Atoh $7^{C K O}$ mice ( $n \geq 7$ mice/genotype at each level). $\boldsymbol{F}$, Percentages (numbers \pm SEM shown in bars on graph) of Islet $1 / 2{ }^{+} \mathrm{L} 2\left(n=7\right.$ mice/genotype) and $\mathrm{L} 4 / 5\left(n=15-18\right.$ mice/genotype) DRG neurons that were TrkC ${ }^{+}$in P0 control and K14; Atoh $7^{C K O}$ mice. In graphs, error bars represent the SEM, and asterisks indicate statistically significant differences between genotypes. ${ }^{*} p<0.05$; ${ }^{* *} p<0.01$. Scale bar, $100 \mu \mathrm{m}$.

We next examined the neurotrophin receptor TrkC, as it is expressed by SAIs and other DRG neurons, including proprioceptors (Airaksinen et al., 1996). Before touch dome innervation at E13.5 and shortly after innervation at E16.5, the percentages of $\mathrm{TrkC}^{+}$and $\mathrm{TrkB}^{+} \mathrm{TrkC}^{+}$ DRG neurons were equivalent in K14; Atoh $1^{C K O}$ mice and control littermates (Fig. $1 E, F, L, M$; Table 1). At $\mathrm{P} 0$, the percentages of $\mathrm{TrkC}^{+}$and $\mathrm{TrkB}^{+} \mathrm{TrkC}^{+}$ DRG neurons were $1.9 \%$ and $2.6 \%$ lower, respectively, in K14; Atoh $1{ }^{\text {CKO }}$ mice versus control littermates (Fig. 1G,H,L,M; Table 1), decreases of similar magnitude to those seen in the $\mathrm{TrkB}^{+}$population. At P21, there were $3.8 \%$ fewer $\operatorname{TrkC}^{+}$DRG neurons in K14; Atoh ${ }^{C K O}$ mice compared with control littermates, while the percentages of $\mathrm{TrkB}^{+} \mathrm{TrkC}^{+}$neurons were comparable (Fig. $1 I, J, L, M$; Table 1). Similar decreases in TrkC expression were found in DRGs at the L2 and L4/5 levels of P0 K14; Atoh1 ${ }^{\text {CKO }}$ mice compared with control littermates, suggesting that this is a generalized phenotype (Fig. 2A-D,F). Furthermore, coimmunostaining for the proprioceptive neuron marker PV (Honda, 1995; de Nooij et al., 2013) and TrkC demonstrated equivalent percentages of $\mathrm{PV}^{+} \mathrm{TrkC}^{+}$DRG neurons in K14; Atoh1 ${ }^{\text {CKO }}$ mice and control littermates at all ages examined (Table 1). These data suggest that Merkel cell deletion affects TrkC expression in a specific population of nonproprioceptor DRG neurons after the onset of touch dome innervation.

Adult SAIs, other mechanoreceptors, and nonpeptidergic nociceptors express the GDNF family receptor Ret (Bourane et
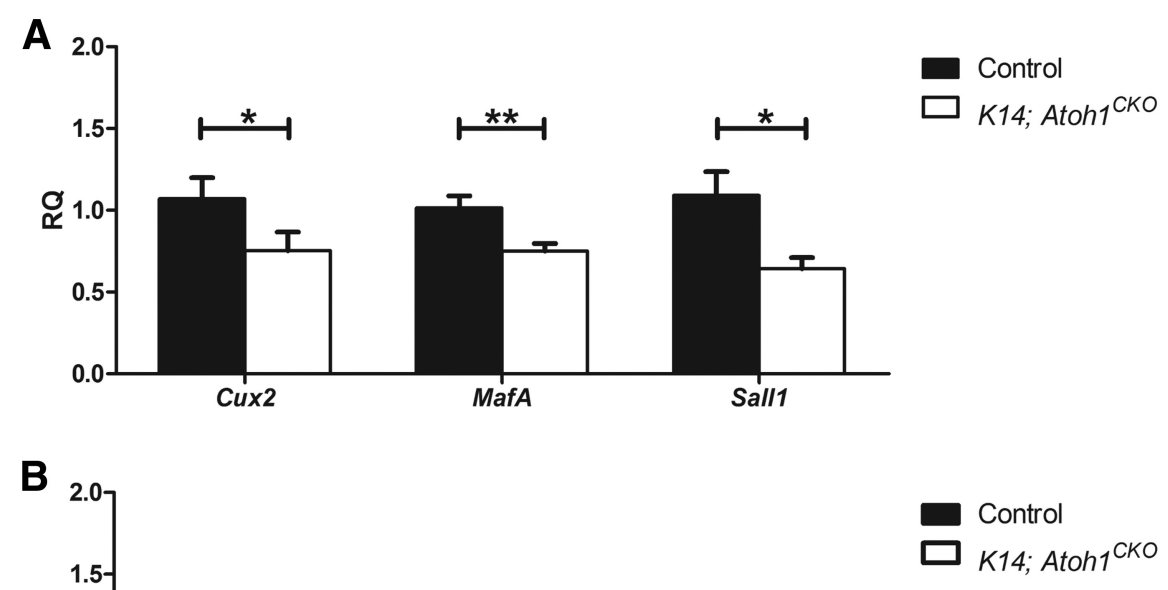

Figure 3. Expression of some transcription factors involved in mechanosensitive DRG neuron development and function are altered by Merkel cell deletion. $\boldsymbol{A}, \boldsymbol{B}$, Expression (qPCR) analysis of mechanoreceptor transcription factors in P0 thoracic DRGs whose expression was decreased $(\boldsymbol{A})$ or unchanged $(\boldsymbol{B})$ in $K 14 ; A$ toh $1^{C K O}$ mice compared with littermate controls ( $n \geq 8$ mice/genotype at each age). Error bars represent the SEM, and asterisks indicate statistically significant differences between genotypes. ${ }^{*} p<0.05 ;{ }^{* *} p<0.01$.

al., 2009; Luo et al., 2009). Percentages of NF200 ${ }^{+}$Ret $^{+}$and TrkC $^{+}$Ret $^{+}$DRG neurons were similar in E13.5, E16.5, and P0 K14; Atoh $1^{C K O}$ mice and control littermates, but P21 K14; Atoh ${ }^{C K O}$ mice had decreases of $3.2 \%$ and $3 \%$, respectively, in these populations compared with littermate controls (Fig. $1 N-S$; Table 1). These data suggest that SAI neurons require Merkel cells for the initiation of Ret expression during the first 3 weeks of postnatal development. 

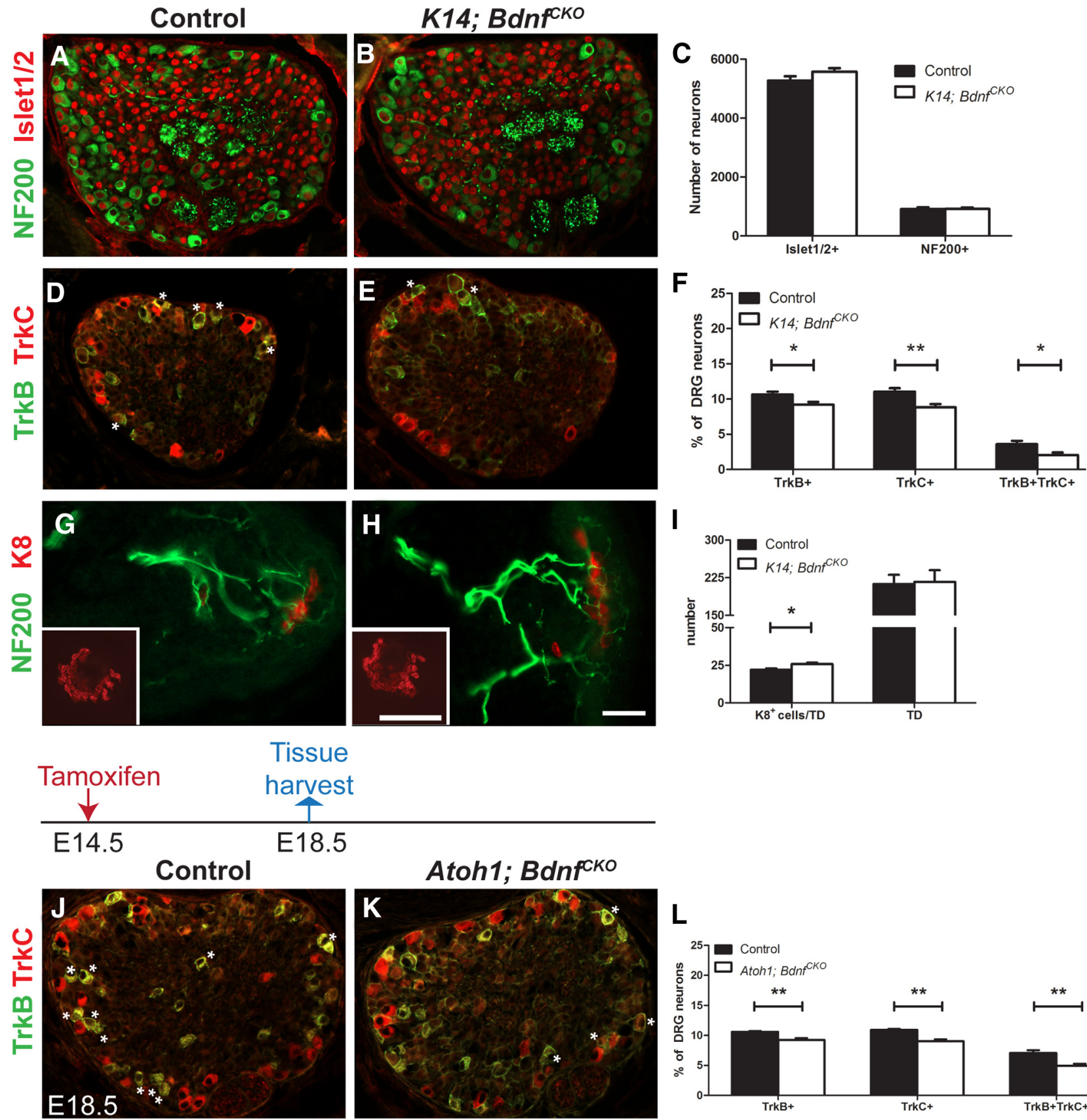

$\mathbf{L}$
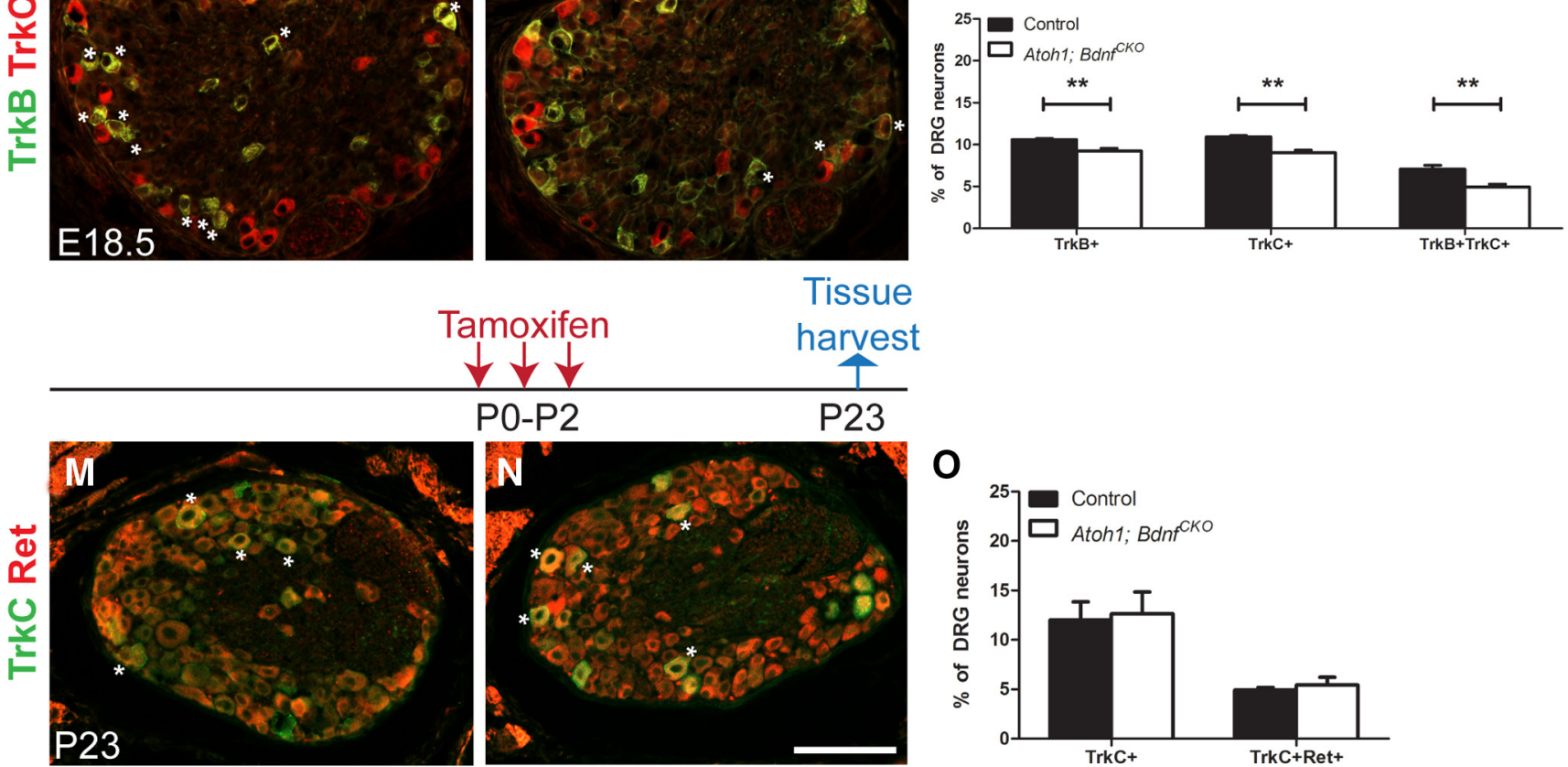

Figure 4. Embryonic but not postnatal Merkel cell-derived BDNF is required for the proper expression of TrkB and TrkC in SAI neurons. $A, B, D, E$, Immunostaining for NF200/slet1/2 (A, B) and TrkB/TrkC (D, E) in T7 DRG sections from PO control and littermate K14; Bdnf ${ }^{C K O}$ mice. Asterisks indicate double-positive cells. $\mathbf{G}, \boldsymbol{H}$, NF200 and K8 immunostaining in dorsal skin sections from P0 control littermate and K14; Bdnf ${ }^{C K O}$ mice. Insets show single touch domes that were whole mount immunostained for K8. C, $\boldsymbol{F}$, The numbers of (Figure legend continues.) 
To determine whether the absence of Merkel cells affected expression of transcription factors associated with mechanoreceptor development, we performed qPCR on reverse-transcribed total RNA from thoracic DRGs of P0 K14; Atoh ${ }^{C K O}$ and control littermates. We found significant decreases in the expression of Cux2, MafA, and Sall1 at P0 (Fig. 3A). Several other genes encoding transcription factors important for DRG neuron maturation (Runx1, Runx3, Shox2) were not affected by Merkel cell deletion (Fig. 3B). These results suggest that the absence of Merkel cells disrupts SAI differentiation/maturation through the dysregulation of transcription factors implicated in mechanoreceptor development.

\section{Merkel cell-derived BDNF is required for neurotrophin receptor expression and BDNF-stimulated signaling in a subset of DRG neurons}

Given that decreases in $\operatorname{TrkB}^{+} \mathrm{DRG}$ neuron numbers preceded decreases in the numbers of $\operatorname{TrkC}^{+}$and Ret $^{+}$DRG neurons in K14; Atoh $1^{C K O}$ mice, we wondered whether disrupted Merkel cell-derived BDNF signaling might underlie these changes in SAI molecular phenotype. To assess this possibility, we conditionally deleted BDNF, the cognate neurotrophin for TrkB, throughout the skin using the $K 14^{C r e}$ allele. P0 K14; $B d n f^{C K O}$ mice had equivalent total and large-diameter neuron numbers but $1.4 \%, 2.3 \%$, and $1.6 \%$, respectively, fewer $\operatorname{TrkB}{ }^{+}, \operatorname{TrkC}^{+}$, and $\operatorname{TrkB}{ }^{+} \operatorname{TrkC}^{+}$ DRG neurons compared with littermate controls (Fig. 4A-F; Table 2). These changes recapitulate those seen after Merkel cell deletion in K14; Atoh $1^{\text {CKO }}$ mice. Importantly, Merkel cell numbers and touch dome innervation were not adversely affected in K14; $B d n f^{C K O}$ mice (Fig. 4G-I). In contrast, P0 K14 ${ }^{\text {Cre }} ; \mathrm{Ntf3} 3^{\text {flox }}$ flox (K14; $N t f 3^{C K O}$ ) mice had an $\sim 20 \%$ decrease in total Islet $1 / 2^{+}$ DRG neuron numbers but no decreases in the numbers of $\mathrm{NF}_{200}{ }^{+}, \mathrm{TrkB}^{+}, \mathrm{TrkC}^{+}$, or TrkB ${ }^{+} \mathrm{TrkC}^{+}$neurons compared with littermate controls (Fig. 5), suggesting that the loss of TrkB and TrkC expression in SAI neurons of K14; $B d n f^{C K O}$ mice is secondary to disrupted BDNF-TrkB signaling, but not to NT3TrkC signaling.

To confirm that Merkel cell-derived BDNF influenced SAI molecular phenotype, we next conditionally deleted $B d n f$ in Merkel cells using a tamoxifen-inducible Atoh $1^{\mathrm{CreER}-T 2}$ allele that faithfully recapitulates endogenous Atohl expression and drives recombination in $>95 \%$ of Merkel cells (Fujiyama et al., 2009; Wright et al., 2015). We administered tamoxifen $(250 \mathrm{mg} / \mathrm{kg})$ to pregnant dams at E14.5 and harvested T7 DRGs from Atoh1 ${ }^{\text {CreER-T2; }}$ $B d n f^{\text {flox/flox }}$ (Atoh1; Bdnf ${ }^{C K O}$ ) embryos at E18.5, a date chosen to avoid birthing complications secondary to tamoxifen administration. Atoh1; Bdnf ${ }^{C K O}$ mice had $1.3 \%, 2.4 \%$ and $2.2 \%$, respectively, fewer $\operatorname{TrkB}^{+}, \operatorname{TrkC}^{+}$, and $\operatorname{TrkB}^{+} \operatorname{TrkC}^{+}$DRG neurons

\section{$\leftarrow$}

(Figure legend continued.) $\quad \mid$ slet $1 / 2{ }^{+}$and NF200 ${ }^{+}$neurons $(\boldsymbol{C} ; n \geq 10$ mice/genotype) and the percentages of Islet $1 / 2^{+}$T7 DRG neurons expressing TrkB and TrkC $(\boldsymbol{F} ; n \geq 6$ mice/genotype) in T7 DRG sections from PO control and K14; Bdnf $f^{\text {KOO }}$ mice. $I$, Numbers of K8 ${ }^{+}$cells/touch dome (TD) and the density of touch domes $/ \mathrm{cm}^{2}$ of skin ( $n=3$ mice/genotype). J-L, Immunostaining for TrkB and TrkC $(\boldsymbol{J}, \boldsymbol{K})$ and the percentage of Islet1/2 ${ }^{+}$T7 DRG neurons expressing TrkB and/or TrkC $(\boldsymbol{L})$ in T7 DRG sections from E18.5 control and Atoh 1; Bdnf ${ }^{C K O}$ mice treated with tamoxifen at E14.5 ( $n=6$ mice/genotype). $\boldsymbol{M}-\mathbf{0}$, Immunostaining for TrkC and $\operatorname{Ret}(\boldsymbol{M}, \boldsymbol{N})$ and the percentage of Islet1/2 ${ }^{+}$T7 DRG neurons expressing TrkC and Ret ( 0 ) in T7 DRG sections from P23 control and Atoh1; Bdnf ${ }^{C K O}$ mice treated with tamoxifen from P0 to P2 ( $n=3$ mice/ genotype). Tamoxifen dosing regimens are shown above $\boldsymbol{J}, \boldsymbol{K}, \boldsymbol{M}$, and $\boldsymbol{N}$. In photographs, asterisks indicate double-labeled cells. In graphs, error bars represent the SEM, and asterisks indicate statistically significant differences between genotypes. ${ }^{*} p<0.05 ;{ }^{* *} p<0.01$. Scale bars: $\boldsymbol{A}, \boldsymbol{B}$, $D, E, J, K, M, N, 100 \mu \mathrm{m} ; \boldsymbol{G}, \boldsymbol{H}, 120 \mu \mathrm{m}$; insets, $40 \mu \mathrm{m}$.
Table 2. Marker expression for T7 DRG neurons in the absence of BDNF

\begin{tabular}{|c|c|c|c|c|c|}
\hline \multirow[b]{2}{*}{ Protein } & \multicolumn{3}{|l|}{ Mice } & \multirow[b]{2}{*}{$n$} & \multirow[b]{2}{*}{$\begin{array}{l}p \\
\text { Value }\end{array}$} \\
\hline & Control & $K 14 ; B d n f^{C K O}$ & $\begin{array}{l}\text { Atoh1 } 1^{\text {CreER-T2; }} \\
\text { Bdnf CKO }\end{array}$ & & \\
\hline \multicolumn{6}{|l|}{ P0 } \\
\hline Islet $1 / 2$ & $5278 \pm 144$ & $5623 \pm 122$ & & 28,29 & 0.07 \\
\hline TrkB & $10.6 \pm 0.43 \%$ & $9.2 \pm 0.39 \%$ & & 12 & 0.02 \\
\hline TrkC & $11.1 \pm 0.47 \%$ & $8.8 \pm 0.48 \%$ & & 12 & 0.003 \\
\hline TrkB/TrkC & $3.6 \pm 0.49 \%$ & $2.0 \pm 0.36 \%$ & & 6,5 & 0.04 \\
\hline NF200/Ret & $2.2 \pm 0.14 \%$ & $2.6 \pm 0.28 \%$ & & 6 & 0.21 \\
\hline PV & $4.3 \pm 0.23$ & $3.9 \pm 0.29$ & & 6 & 0.31 \\
\hline \multicolumn{6}{|c|}{ E14.5 Tam $\rightarrow$ E18.5 } \\
\hline Islet $1 / 2$ & $6050 \pm 199$ & & $5968 \pm 215$ & 7 & 0.78 \\
\hline TrkB & $10.6 \pm 0.11 \%$ & & $9.3 \pm 0.27 \%$ & 4 & 0.004 \\
\hline TrkC & $11.1 \pm 0.34 \%$ & & $8.7 \pm 0.39 \%$ & 6 & 0.001 \\
\hline TrkB/TrkC & $7.1 \pm 0.47 \%$ & & $4.9 \pm 0.36 \%$ & 6 & 0.005 \\
\hline \multicolumn{6}{|c|}{$\mathrm{P} 0-\mathrm{P} 2 \mathrm{Tam} \rightarrow \mathrm{P} 23$} \\
\hline Islet 1/2 & $4776 \pm 213$ & & $4928 \pm 350$ & 3 & 0.73 \\
\hline TrkC & $12.0 \pm 1.85 \%$ & & $12.6 \pm 2.22 \%$ & 3 & 0.84 \\
\hline TrkC/Ret & $4.9 \pm 0.27 \%$ & & $5.4 \pm 0.79 \%$ & 3 & 0.59 \\
\hline
\end{tabular}

Values are given as T7 DRG neuron counts and the percentages of total neuron numbers expressing different markers

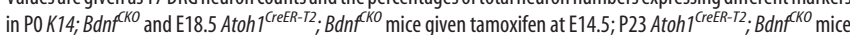
given tamoxifen from PO to P2; and control littermate mice; and are reported as the mean \pm SEM, unless otherwised indicated.

compared with littermate controls, reproducing the phenotypes seen in K14; Atoh $1^{C K O}$ and K14; Bdnf ${ }^{C K O}$ mice (Fig. 4J-L; Table 2). Significantly, tamoxifen administration from $\mathrm{P} 0$ to $\mathrm{P} 3 \mathrm{did}$ not alter the percentages of $\mathrm{TrkC}^{+}$or $\mathrm{TrkC}^{+} \mathrm{Ret}^{+}$neurons at P23 (Fig. 4M-O; Table 2). These data demonstrate that Merkel cellderived BDNF is necessary for SAI neuron molecular differentiation/maturation during a specific embryonic critical period.

BDNF binding to TrkB induces intra-axonal translation of SMAD1/5/8, which is then phosphorylated to an active form that translocates to the neuronal cell body, where it subsequently mediates transcription of the transcriptional repressor Tbx3 (Ji and Jaffrey, 2012). Percentages of $\mathrm{NF} 200^{+} \mathrm{pSMAD} 1 / 5 / 8^{+}$and $\mathrm{NF} 200^{+} \mathrm{Tbx}^{+}{ }^{+} \mathrm{DRG}$ neurons were comparable in E13.5 K14; Atoh $1^{\text {CKO }}$ mice and littermate controls, but those percentages were decreased by $4.8 \%$ and $3.3 \%$, respectively, in E16.5 K14; Atoh $1^{C K O}$ mice compared with littermate controls (Fig. $6 A-K$ ). Furthermore, quantitative PCR on thoracic DRGs of P0 K14; Atoh $1^{C K O}$ mice and littermate controls demonstrated reductions in the expression of the BDNF-responsive genes Egr1, Fos, Nr4a1, and $T b \times 3$ (Fig. $6 L$ ). These data suggest that Merkel cell deletion causes a failure to activate downstream BDNF signaling in SAI neurons.

\section{$B d n f$ deletion in embryonic Merkel cells causes abnormal SAI responses}

Constitutive $B d n f$ deletion affects slowly adapting peripheral mechanoreceptor electrophysiological responses (Carroll et al., 1998), so we wondered whether embryonic loss of Merkel cellderived BDNF would lead to changes in SAI electrophysiological phenotype. To test this, we characterized SAI responses in dorsal foot skin-saphenous nerve preparations from adult Atoh1; $B d n f^{C K O} ; R_{O S A^{\text {tdTomato }}}$ Atoh1; Bdnflox/+ $;$ ROSA $^{\text {tdTomato }}$, and control littermate mice that received tamoxifen at E14.5. In Atoh1; $B d n f^{C K O} ; R^{2 O S A^{\text {tdTomato }}}$ and Atoh1; Bdnflox/+ $;$ ROSA $^{\text {tdTomato }}$ mice, tamoxifen administration deleted $B d n f^{\text {flox }}$ from Atoh1-expressing cells while simultaneously activating tdTomato expression from the ROSA locus (Madisen et al., 2010). Using tdTomato reporter 

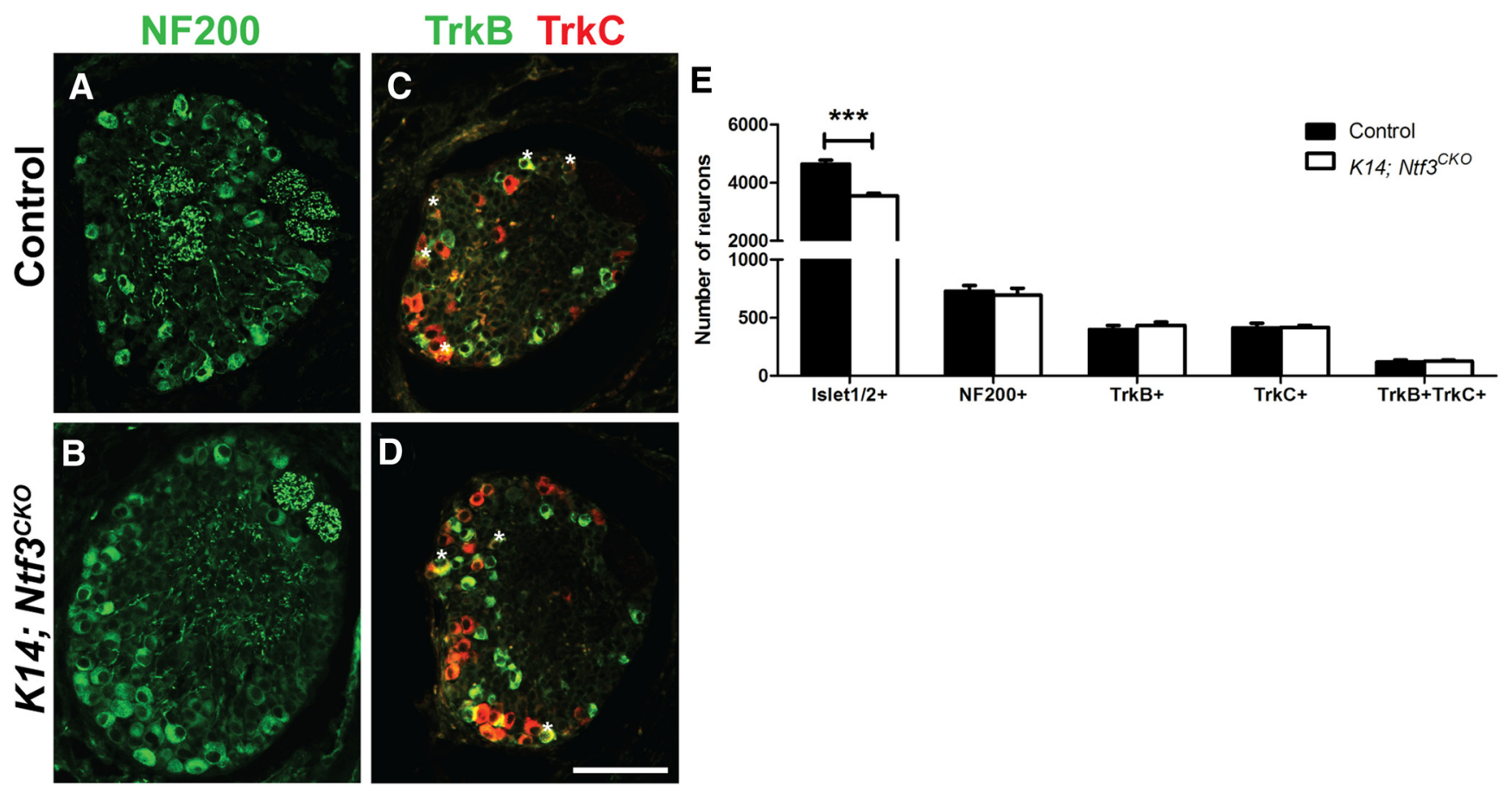

Figure 5. Skin-derived NT3 does not regulate DRG neuron Trk expression. A-D, Immunostaining for NF200, TrkB, and TrkC in T7 DRG sections from P0 control littermate and K14; Ntf3 ${ }^{C K O}$ mice.

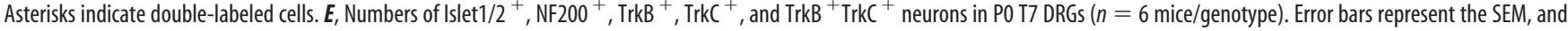
asterisks indicate statistically significant differences between genotypes. ${ }^{* * *} p<0.001$. Scale bar, $100 \mu \mathrm{m}$.

expression as a readout of Cre-mediated recombination, we unexpectedly found that tdTomato ${ }^{+}$Merkel cells were present proximally but absent distally (Fig. $7 A$ ). This suggested that Cre-mediated recombination occurred only proximally, likely due to differences in the birth dates of and, hence, Atoh1 expression by Merkel cells in these regions (our unpublished observations). This unexpected finding gave us the opportunity to compare electrophysiological responses in the presence and absence of Merkel cell-derived BDNF in Atoh1; Bdnf ${ }^{C K O}$; ROSA ${ }^{\text {tdTomato }}$ mice.

We first classified recorded cells into groups based on conduction velocity $(\mathrm{A} \beta, \mathrm{A} \delta$, and $\mathrm{C})$ and response properties (rapidly vs slowly adapting; Fig. $7 B$; for a detailed description, see Materials and Methods). Thresholds and firing rates in response to constant force were not significantly different among control, Atohl; $B d n f^{\text {flox/+ }} ; R_{O S A} A^{\text {tdTomato }}$, and Atoh $1 ; B d n f^{C K O} ; R^{2} O S A^{\text {tdTomato }}$ mice for high threshold, RA, or slowly adapting type I fibers (Table 3 ). Subsequent analyses were limited to slowly adapting $\mathrm{A} \beta$ fibers, which were divided into the following two groups: (1) classic SA1 $\mathrm{A} \beta$ fibers with an irregular discharge pattern $(\mathrm{CoV},>0.7)$ and narrow dynamic range $(1-10 \mathrm{mN})$, consistent with insensitivity to stimulus intensity; and (2) regularly firing ( $\mathrm{CoV}, \leq 0.7)$ HTMR fibers that encode intensity over a wide dynamic range $(5-50 \mathrm{mN}$; Brown and Iggo, 1967; Horch et al., 1974; McIlwrath et al., 2007). No differences in these groups were observed between control and Atoh1; Bdnf flox/+ $;$ ROSA ${ }^{\text {tdTomato }}$ mice, so their results were combined for all analyses. We found that both types of responses were elicited by distal foot hairy skin mechanical stimulation of Atoh $1 ; B d n{ }^{C K O}$; ROSA ${ }^{\text {tdTomato }}$ mice (Fig. 7 B, C). In contrast, $75 \%$ of fibers (six of eight fibers) recorded in the proximal foot skin of Atoh1; Bdnf ${ }^{C K O} ; R^{2} O S A^{\text {tdTomato }}$ mice exhibited a narrow dynamic range coupled with a regular firing pattern (Fig. $7 B-D$ ). This hybrid group combined features of SAI and HTMR afferents and was never seen in control mice. These data suggest that the dele- tion of $B d n f$ in embryonic Merkel cells affects the electrophysiological characteristics of SAI neurons.

We next sought to correlate these electrophysiological changes with changes in the expression of ion channels and neurotransmitter receptors implicated in mechanosensation. Quantitative PCR on cDNA from thoracic DRGs of P21 K14; Atoh1 ${ }^{\text {CKO }}$ mice and littermate controls demonstrated decreased expression of Scnnlg, which encodes the $\gamma \mathrm{ENaC}$ subunit; increased expression of Asicl, which encodes a proton-gated sodium channel; and increased expression of Oprd1, which encodes the $\delta$ opioid receptor (Fig. 8A). The expression levels of several other ion channels and transporters (Asic2, Asic3, Kv1.1, Piezo2, Scnn1b, Slc17a6, Slc17a7, Slc17a8, TrpC1, and TrpV4) were comparable in K14; Atoh $1^{\text {CKO }}$ mice and littermate controls (data not shown). To confirm that these changes were specific to SAI neurons, we immunostained DRG tissue sections for $\gamma \mathrm{ENaC}$, Asicl, or DOR. The percentage of $\mathrm{NF}_{200}{ }^{+} \gamma \mathrm{ENaC}^{+}$DRG neurons was reduced by $3.6 \%$ in P21 K14; Atoh1 ${ }^{C K O}$ mice compared with littermate controls (Fig. $8 \mathrm{~B}, \mathrm{C}, \mathrm{H}$; Table 1 ), which is a change that is consistent with the magnitude of the $\mathrm{qPCR}$ results. There were no differences in the percentages of $\mathrm{NF}_{200}{ }^{+} \mathrm{Asicl}{ }^{+}$or NF200 ${ }^{+}$DOR $^{+}$DRG neurons between genotypes (Fig. $8 D-H$; Table 1), suggesting that increased ASIC1 and Oprd1 expression occurs in SAI neurons rather than through the recruitment of additional DRG neurons following Merkel cell deletion. These data identify potential molecular mechanisms that might underlie the novel electrophysiological responses seen in K14; Atoh ${ }^{C K O}$ mice.

\section{Discussion}

We used the Merkel cell-neurite complex as a model to study how skin targets influence somatosensory neuron maturation. Our data suggest that the developmental regulation of SAI molecular phenotype by Merkel cell-derived BDNF is similar to the 


\section{NF200 pSMAD1/5/8}

E13.5
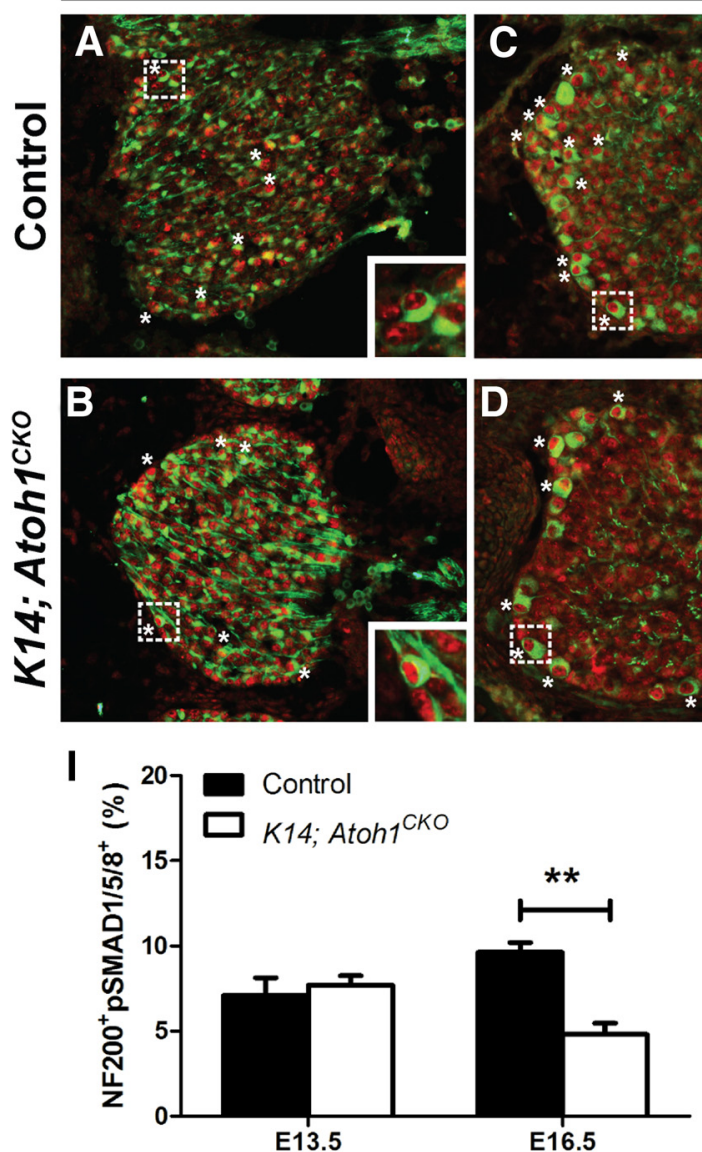

NF200 Tbx3

E13.5
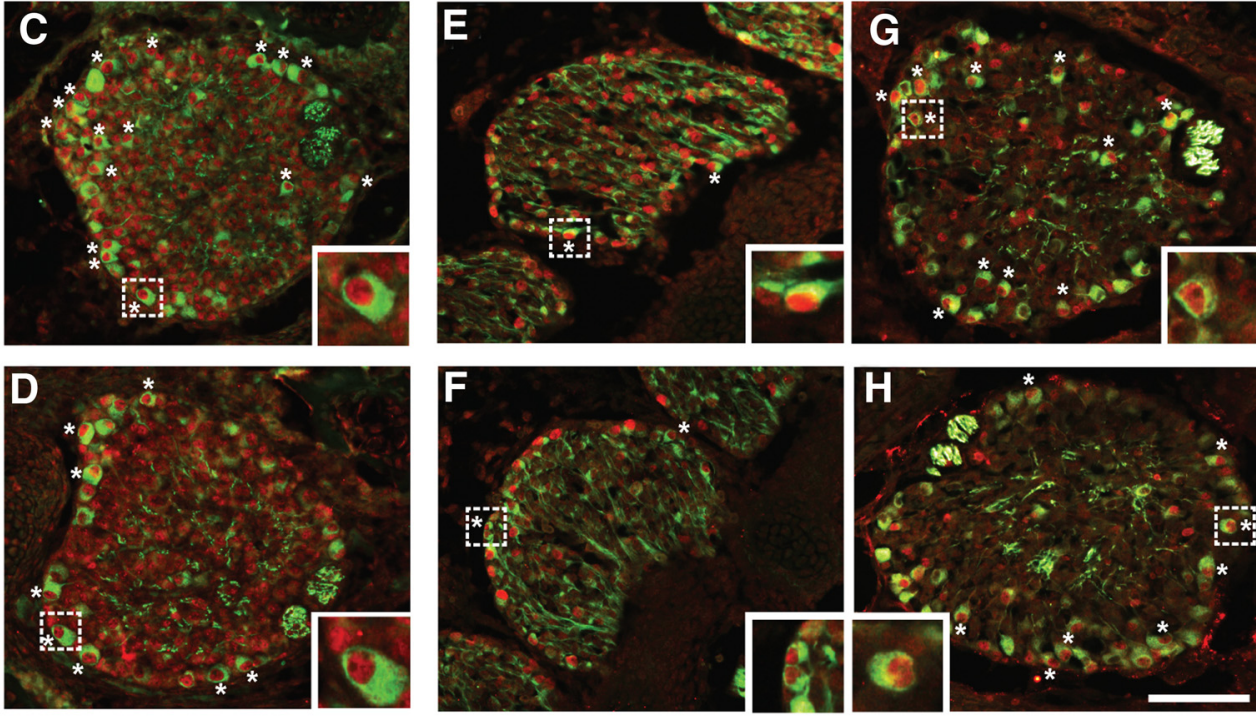

J

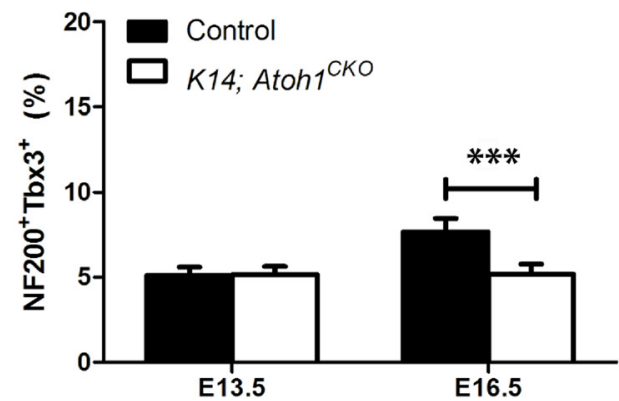

K

\begin{tabular}{|l|l|l|l|l|}
\hline Protein & Control & K14; $^{\text {Bdnf }}$ CKO $^{\text {n }}$ & n & p-value \\
\hline pSMAD1/5/8 & $9.62 \pm 0.59$ & $4.80 \pm 0.68$ & 4 & 0.002 \\
\hline Tbx3 & $8.01 \pm 0.51$ & $4.67 \pm 0.42$ & 6 & 0.0005 \\
\hline
\end{tabular}

L

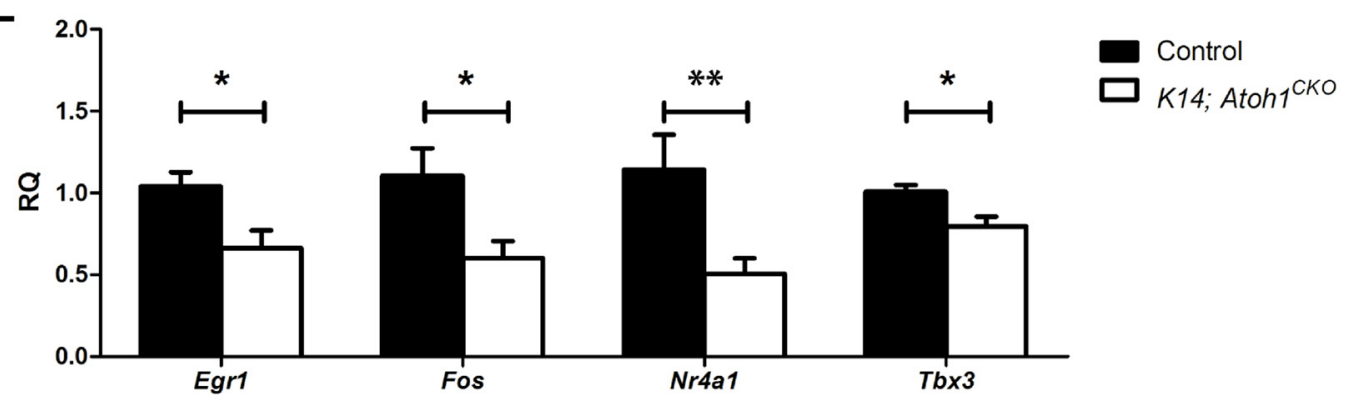

Figure 6. Merkel cell deletion reduces BDNF-stimulated signaling in SAI neurons and alters transcription factor expression. $\boldsymbol{A}-\boldsymbol{H}$, Immunostaining for NF200 and phospho-SMAD1/5/8 (A-D) or Tbx3 $(\boldsymbol{E}-\boldsymbol{H})$ in T7 DRG sections from E13.5 and E16.5 control littermate and K14; Atoh $1^{\mathrm{CKO}}$ mice. Asterisks indicate double-positive cells. I, J, The mean percentage of Islet1/2 ${ }^{+}$T7 DRG neurons that were NF200 ${ }^{+}$pSMAD1/5/8 ${ }^{+}(\boldsymbol{I})$ and NF200 ${ }^{+} \mathrm{Tbx3}^{+}(\boldsymbol{J})$ in E13.5 and E16.5 control and $\mathrm{K14} ;$ Atoh $1^{\mathrm{CKO}}$ mice $\left(n \geq 3\right.$ mice/genotype at each age). $\boldsymbol{K}$, Percentage of pSMAD1/5/8 ${ }^{+} \mathrm{NF200}{ }^{+}$or $\mathrm{Tbx}^{+}{ }^{+} \mathrm{NF} 200{ }^{+}$neurons in E13.5 and E16.5 control littermate and K14; Atoh $1^{\mathrm{CKO}}$ mice. $L$, qPCR analysis of genes regulated by BDNF signaling ( $n \geq 8$ mice/genotype). In photographs, asterisks indicate double-labeled cells. In graphs, error bars represent the SEM, and asterisks indicate statistically significant differences between genotypes. ${ }^{*} p<0.05{ }^{* *} p<0.01$; ${ }^{* *} p<0.001$. Scale bar, $100 \mu \mathrm{m}$.

role of target-derived factors that instruct the phenotypes of sympathetic and motor neurons (Luther and Birren, 2009; Stifani, 2014). One limitation of our study is that there are no specific markers for SAI neurons, which forced us to examine the entire DRG population for our molecular analyses. However, several factors suggest that the changes in protein and mRNA expression that we observed in the DRGs were limited to SAI neurons. First, SAI neurons are the only DRG neurons that target Merkel cells, making it unlikely that other DRG neuron populations would be affected by Merkel cell loss or loss of Merkel cell-derived BDNF. Second, we observed expression changes only after Merkel cell innervation commences at E14.5, which links the 

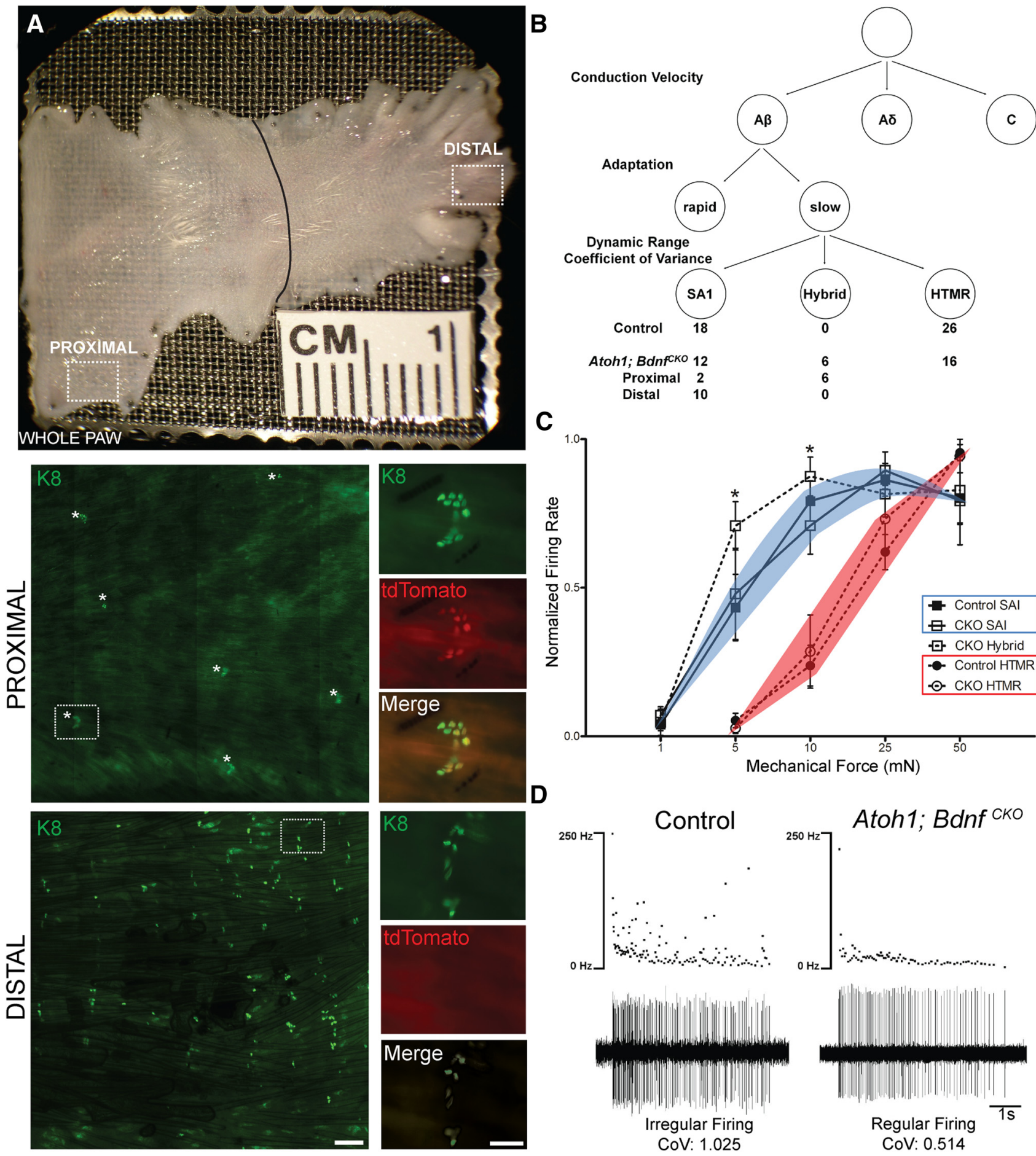

Figure 7. Embryonic Bdnf deletion in Merkel cells alters SAl neuron electrophysiological phenotype. $A$, Bright-field image of dorsal foot skin from P64 Atoh1; Bdnf $f^{C K O} ; R 0 S A^{\text {tdTomato }}$ mouse given tamoxifen at E14.5 used for skin-nerve recording preparation. Endogenous tdTomato signal and immunostaining for K8 demonstrates near-complete recombination in proximal foot, but very little recombination in distal foot. Scale bars: low magnification, $200 \mu \mathrm{m}$; insets, $50 \mu \mathrm{m}$. B, Classification of electrophysiological responses in control and Atoh1; Bdnf ${ }^{C K O} ; R 0 S A^{t d T o m a t o}$ mice. Recorded fibers were first classified by conduction velocity and adaptation characteristics, then slowly adapting $A \beta$ fibers were subdivided by their dynamic range and firing pattern CoV. SAI neurons had a $\mathrm{CoV}>0.7$ and a small dynamic range $(1-10 \mathrm{mN})$, while HTMRs fired regularly $(\mathrm{CoV},<0.7)$ with a wide dynamic range $(5-50 \mathrm{mN})$. Hybrid responses exhibited a regular firing pattern $(\mathrm{CoV},<0.7)$ and a narrow dynamic range (1-10 mN). Regular firing afferents from the $A t o h 1 ; B d n f^{f K O} ; R O S A^{\text {tdTomato }}$ mice are split into proximal and distal, based on their innervation fields. The numbers of each response type for control and $A$ toh1; $B d n f^{C K O}$ mice are under the respective cell type. C, Normalized firing rates with SEM of slowly adapting A $\beta$ fibers from control and $A t o h 1 ; B d n f^{K K O}$ mice. ${ }^{*} p<0.05$ difference from control SAI. D, Representative spike traces from proximal control SAl and Atoh1; Bdnf $f^{\complement K O}$; ROSA ${ }^{\text {tdTomato }}$ hybrid neurons.

changes with Merkel cell contact. Third, $\sim 3 \%$ of the DRG neuron population lost TrkB, TrkC, and/or Ret expression following Merkel cell or $B d n f$ deletion, a fraction similar to the $\sim 3 \%$ of mouse cutaneous sensory neurons that are SAI in electrophysiological phenotype (Lawson et al., 2008). Fourth, the magnitude of the observed expression changes was consistent across a variety of different markers, including doubleimmunostaining for TrkB/TrkC and TrkC/Ret. This again 
Table 3. Mechanoreceptor thresholds for littermate control and Atoh ${ }^{\text {CreER-T2 }}$; $B d n f^{C K O}$ mice given tamoxifen at E14.5

\begin{tabular}{llll}
\hline & \multicolumn{2}{l}{ Mice $(\mathrm{mN})$} & \\
\cline { 2 - 4 } Fiber type & Control & Atoh $^{\text {CreER-T2 }}$;Bdnf KKO $^{\text {B }}$ & $n$ \\
\hline Slowly adapting HTMR & 9.0 & 10.0 & 25,16 \\
Rapidly adapting LTMR & 6.15 & 6.26 & 25,26 \\
Slowly adapting type I & 4.42 & 4.5 & 12,8 \\
\hline
\end{tabular}

LTMR, Low-threshold mechanoreceptor.

suggests that the same group of neurons is involved. Finally, the loss of SAI but not other cutaneous mechanoreceptor responses in Atoh1; Bdnf $f^{C K O} ; R_{O S A^{\text {tdTomato }}}$ mice suggests a specific functional effect. Together, these observations strongly suggest that our molecular marker studies identify a single population of DRG neurons that is affected by Merkel cell loss or deletion of Merkel cell-derived BDNF.

Expression patterns of TrkB, TrkC, and Ret change dramatically during DRG neuron maturation (for review, see Ernsberger, 2009). Our findings suggest that SAI neurons are $\operatorname{TrkB}^{+} \operatorname{TrkC}^{+}$ embryonically and neonatally, but switch to $\operatorname{TrkC}^{+} \mathrm{Ret}^{+}$postnatally (Fig. 1). This observation illuminates a previously unappreciated dynamic, developmentally regulated expression of these receptors in SAI neurons. Surprisingly, our data also suggest that maintained TrkC expression and the initiation of Ret expression is driven by BDNF-TrkB signaling. We propose a model where BDNF produced by embryonic Merkel cells binds TrkB on SAI neurons to activate a number of different signaling pathways, including the phospho-SMAD/Tbx3 signaling axis (Fig. 9). These various cascades then initiate expression of the transcription factors Egr1, Fos, Nr4a1, Tbx3, Cux2, MafA, and Sall1; maintain TrkC expression; and initiate Ret expression (Hughes and Dragunow, 1995; Andrew et al., 2002; Nishida et al., 2008; Bourane et al., 2009; Davis and Puhl, 2011; Ji and Jaffrey, 2012). Conversely, the loss of BDNF signaling fails to induce the expression of these transcription factors, which in turn leads to failures to maintain TrkC and initiate Ret expression (Fig. 9). This interpretation is consistent with the observations that TrkC is downstream of Fos (Hughes and Dragunow, 1995), and that Ret is downstream of Egr1 and requires MafA for maintained expression (Andrew et al., 2002; Bourane et al., 2009). Furthermore, our data show that these effects are specific for the BDNFTrkB pathway, as TrkC expression in SAI neurons is maintained following skin-specific NT3 deletion. The developmental window during which SAI neuron maturation requires Merkel cellderived BDNF is short, as the deletion at P0-P2 does not affect TrkC or Ret expression (Fig. 4M-O). This is also consistent with the observation that postnatal Merkel cells do not express $B d n f$ (Haeberle et al., 2004).

Our results also provide insights into transcriptional regulation of SAI neuron identity. We found changes in mRNA expression levels of three transcription factors (Cux2, MafA, Sall1) that have been implicated in mechanoreceptor development (Bourane et al., 2009; de Celis and Barrio, 2009; Bachy et al., 2011). Cux2 is a homeodomain protein involved in $\mathrm{A} \delta$ neuron mechanosensitivity that is also expressed by embryonic TrkB ${ }^{+}$ and $\mathrm{TrkC}^{+}$DRG neurons, although its function in these latter groups is unknown (Bachy et al., 2011). MafA positively regulates Ret expression and is expressed by several mechanoreceptors including SAI neurons (Bourane et al., 2009; Wende et al., 2012). Sall1, a zinc finger transcription factor that is a transcriptional activator, is required for the specification and terminal differentiation of sensory neurons (Hu et al., 2006; de Celis and
Barrio, 2009). Our results suggest that all of these genes are downstream of BDNF-TrkB signaling in SAI neurons. Furthermore, the fact that expression levels of several other transcription factors important for DRG neuron maturation were not affected by Merkel cell deletion suggests that changes in Cux2, MafA, and Sall1 are all specific to SAI neurons. To what extent the decreased expression of these genes mediates the aberrant SAI molecular and electrophysiological phenotypes observed following Merkel cell ablation or loss of Merkel cellderived BDNF remains to be studied.

Our data demonstrate that Merkel cells are important for the maturation of SAI electrophysiological properties, as Merkel cellspecific $B d n f$ deletion led to the appearance of cutaneous somatosensory afferents with properties intermediate to SAI afferents and $\mathrm{A} \beta$ HTMRs. These hybrid responses were found only in the proximal foot skin of Atoh1; Bdnf ${ }^{C K O}$ mice, where $>95 \%$ recombination occurred, and were never seen in control mice or in distal foot regions of Atoh1;Bdnf ${ }^{C K O}$ foot skin where Merkel cells did not undergo recombination. Some normal SAI responses persisted in the proximal foot skin of Atoh1; $B d n f^{C K O}$ mice, likely due to those neurons innervating the small fraction of nonrecombined Merkel cells. The presence of these hybrid fibers raises the interesting possibility that these neurons might arise from a common progenitor that gives rise to neurons with a slowly adapting, regularly firing phenotype, and that embryonic Merkel cell-derived BDNF signaling subsequently alters the SAI phenotype from this default pattern. In support of this theory all non-SAI, myelinated, slowly adapting somatosensory afferents, including proprioceptors, exhibit regular firing rates, and many of these neurons (including a population of A-fiber HTMRs) are TrkC $^{+}$(Horch et al., 1974; McIlwrath et al., 2007; de Nooij et al., 2013). Furthermore, our data suggest three candidate genes (Asic1, Scnng1, and Oprd1), all of which are normally expressed by SAI neurons (Drummond et al., 2000; Bardoni et al., 2014; P.C. Adelman and H.R. Koerber, unpublished data), that might shape SAI firing properties. Asicl encodes a proton-gated sodium channel that mediates glutamate-independent calcium entry into neurons (Waldmann et al., 1997). Scnn1g is an Asicl paralog that encodes $\gamma \mathrm{ENaC}$, a sodium channel that functions in action potential propagation (Raouf et al., 2012). Oprd1 encodes the $\delta$ opioid receptor, which is a G-protein-coupled receptor that regulates neurotransmission (Williams et al., 2001; Bardoni et al., 2014). We speculate that increased expression of Asic1 and Oprd1 accompanied by decreased expression of Scnn1g contributes to the aberrant firing properties of SAI afferents seen in Atoh1; $B D N F^{C K O}$ mice. Additional experiments are necessary to verify this hypothesis.

A previous study (Carroll et al., 1998) concluded that slowly adapting cutaneous mechanoreceptors had decreased mechanical sensitivity in $B d n f^{+/-}$and $B d n f^{-/-}$mice, and that "normal" electrophysiological responses in adult animals could be rescued by intraperitoneal BDNF administration. However, we did not see differences in the mechanical thresholds of slowly adapting fibers in control versus Atoh1; Bdnf ${ }^{C K O}$; ROSA $A^{\text {tdTomato }}$ mice. There are several potential reasons for the differing results between the two studies. One possibility is that non-Merkel cellderived BDNF sources, such as local production within the DRG (De Biasi and Rustioni, 1988; Apfel et al., 1996; Zhou and Rush, 1996; Conner et al., 1997; Michael et al., 1997), might also influence SAI function. These sources are retained in our Merkel cell-specific $B d n f$ knockouts but are lost in $B d n f^{-/-}$ mice. This interpretation is supported by the observation by Carroll et al. (1998) of differing mechanical thresholds be- 
A
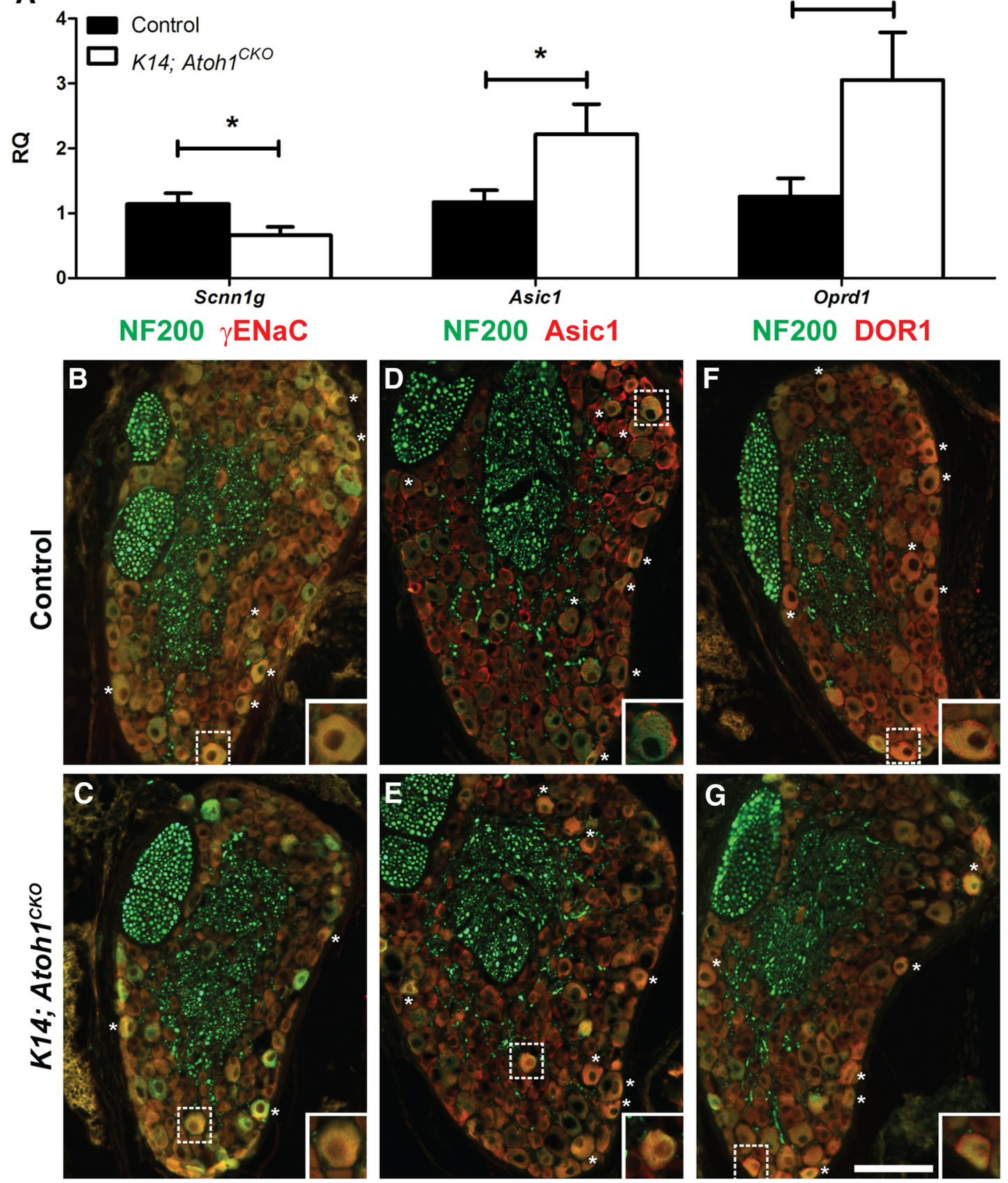

(2)
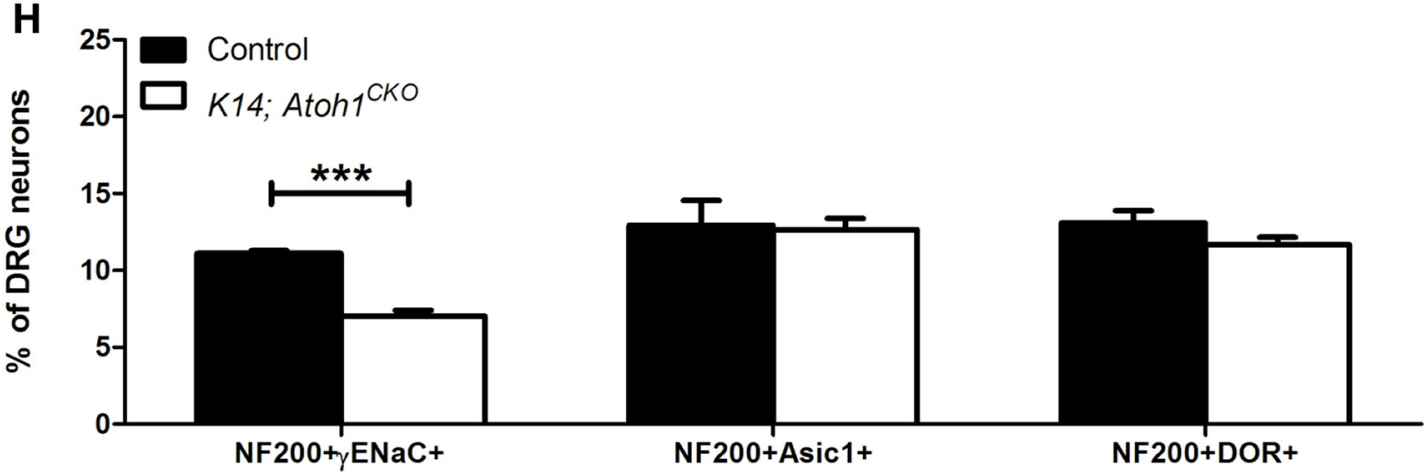

Figure 8. Merkel cell deletion alters the expression of SAl ion channel components. A, qPCR analysis of ion channels in P21 thoracic DRGs ( $n \geq 8$ mice/genotype at each age). $\boldsymbol{B}-\mathbf{G}$, Immunostaining for NF200, $\gamma \mathrm{ENaC}$, Asic1, and DOR in T7 DRG sections from P21 control littermate and $K 14 ;$ Atoh $7^{\mathrm{CKO}}$ mice. Asterisks indicate double-positive cells. $\boldsymbol{H}$, Percentages of Islet1/2 ${ }^{+} \mathrm{T} 7 \mathrm{DRG}$ neurons that were $\mathrm{NF}_{200}{ }^{+} \gamma \mathrm{ENaC}{ }^{+}, \mathrm{NF} 200^{+} \mathrm{Asic} 1$, and NF200 ${ }^{+} \mathrm{DOR}{ }^{+}$in P21 control and $\mathrm{K} 14 ;$; Atoh $7^{\mathrm{CKO}}$ mice ( $n \geq 3$ mice/genotype). Error bars in graphs represent the SEM, and asterisks indicate statistically significant differences between genotypes. ${ }^{*} p<0.05,{ }^{* * *} p<0.001$. 


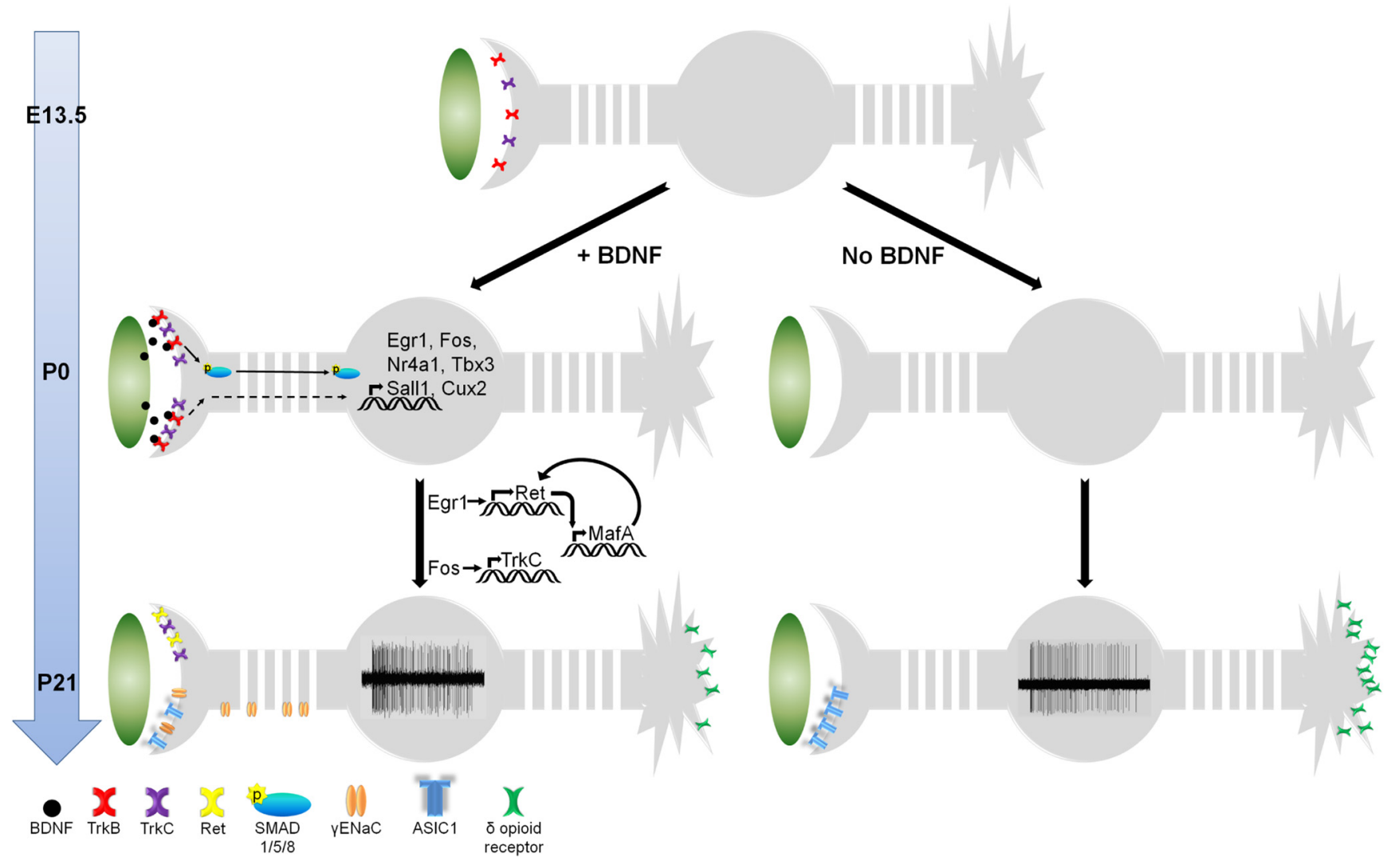

Figure 9. Model for how Merkel cell-derived BDNF specifies SAl neuron molecular and electrophysiological phenotypes. In wild-type mice (left side), BDNF released from embryonic Merkel cells binds TrkB expressed on SAI neuron peripheral terminals, initiating signaling cascades that induce expression of the transcription factors Egr1, Fos, Nr4a1, Tbx3, Cux2, MafA, and Sall1. Fos maintains TrkC expression (Hughes and Dragunow, 1995), Egr1 initiates and MafA maintains Ret expression (Andrew et al., 2002; Bourane et al., 2009), and transcription factors like Cux2 coordinate ion channel expression (Bachy et al., 2011), all of which contribute to SAI neuron excitability and mature electrophysiological properties. In contrast, BDNF deletion during the embryonic period (right side) prevents the activation of these signaling cascades, which in turn leads to failed expression of TrkC and Ret along with misexpression of ion channels.

tween control and $B d n f^{+/-}$mice, while we did not see differences between control and Atoh1; Bdnf CKO; ROSA ${ }^{\text {tdTomato }}$ mice. Methodological differences are another possibility, as we stimulate on the epidermal surface while Carroll et al. (1998) used an inverted preparation. The Carroll et al. (1998) study also did not subdivide the slowly adapting mechanoreceptor population into SAI and HTMR subtypes based on the regularity of firing, and they could have therefore missed the appearance of regularly firing afferents with low-dynamic intensity coding. This might also explain why exogenous BDNF in their system was sufficient to improve slowly adapting mechanoreceptor thresholds, as BDNF from other sources might be necessary for HTMR function. Whether SAI neuron maturation can be rescued following embryonic $B d n f$ deletion in our system has not been tested.

Previous studies concluded that Merkel cell function is necessary for canonical SAI electrophysiological responses (Maricich et al., 2009; Maksimovic et al., 2014; Woo et al., 2014). In those studies, dynamic and static phases of SAI firing were altered by Merkel cell deletion, but only the static phase was altered by Piezo2 deletion or optogenetic Merkel cell silencing. Our data are consistent with these studies and provide a possible explanation for the differing results seen in the presence and absence of Merkel cells; namely, that Merkel cell-derived BDNF is important for the development of normal SAI dynamic phase responses. In summary, our findings provide new insights into the regulation of somatosensory neuron develop- ment and reveal a novel way in which Merkel cells participate in mechanosensation.

\section{References}

Airaksinen MS, Koltzenburg M, Lewin GR, Masu Y, Helbig C, Wolf E, Brem G, Toyka KV, Thoenen H, Meyer M (1996) Specific subtypes of cutaneous mechanoreceptors require neurotrophin-3 following peripheral target innervation. Neuron 16:287-295. CrossRef Medline

Albers KM, Perrone TN, Goodness TP, Jones ME, Green MA, Davis BM (1996) Cutaneous overexpression of NT-3 increases sensory and sympathetic neuron number and enhances touch dome and hair follicle innervation. J Cell Biol 134:487-497. CrossRef Medline

Andrew SD, Capes-Davis A, Delhanty PJ, Marsh DJ, Mulligan LM, Robinson BG (2002) Transcriptional repression of the RET proto-oncogene by a mitogen activated protein kinase-dependent signalling pathway. Gene 298:9-19. CrossRef Medline

Apfel SC, Wright DE, Wiideman AM, Dormia C, Snider WD, Kessler JA (1996) Nerve growth factor regulates the expression of brain-derived neurotrophic factor mRNA in the peripheral nervous system. Mol Cell Neurosci 7:134-142. CrossRef Medline

Bachy I, Franck MC, Li L, Abdo H, Pattyn A, Ernfors P (2011) The transcription factor Cux2 marks development of an A-delta sublineage of TrkA sensory neurons. Dev Biol 360:77-86. CrossRef Medline

Bardoni R, Tawfik VL, Wang D, François A, Solorzano C, Shuster SA, Choudhury P, Betelli C, Cassidy C, Smith K, de Nooij JC, Mennicken F, O’Donnell D, Kieffer BL, Woodbury CJ, Basbaum AI, MacDermott AB, Scherrer G (2014) Delta opioid receptors presynaptically regulate cutaneous mechanosensory neuron input to the spinal cord dorsal horn. Neuron 81:1312-1327. CrossRef Medline

Bates B, Rios M, Trumpp A, Chen C, Fan G, Bishop JM, Jaenisch R (1999) 
Neurotrophin-3 is required for proper cerebellar development. Nat Neurosci 2:115-117. CrossRef Medline

Ben-Arie N, Hassan BA, Bermingham NA, Malicki DM, Armstrong D, Matzuk M, Bellen HJ, Zoghbi HY (2000) Functional conservation of atonal and Math1 in the CNS and PNS. Development 127:1039-1048. Medline

Bourane S, Garces A, Venteo S, Alex, Pattyn A, Hubert T, Fichard A, Puech S, Boukhaddaoui H, Baudet C, Takahashi S, Valmier J, Carroll P (2009) Low-threshold mechanoreceptor subtypes selectively express MafA and are specified by Ret signaling. Neuron 64:857-870. CrossRef Medline

Brown AG, Iggo A (1967) A quantitative study of cutaneous receptors and afferent fibres in the cat and rabbit. J Physiol 193:707-733. CrossRef Medline

Carroll P, Lewin GR, Koltzenburg M, Toyka KV, Thoenen H (1998) A role for BDNF in mechanosensation. Nat Neurosci 1:42-46. CrossRef Medline

Casserly I, Thambipillai T, Macken M, FitzGerald MJ (1994) Innervation of the tylotrich-touch dome complexes in rat skin: changing patterns during postnatal development. J Anat 185:553-563. Medline

Conner JM, Lauterborn JC, Yan Q, Gall CM, Varon S (1997) Distribution of brain-derived neurotrophic factor (BDNF) protein and mRNA in the normal adult rat CNS: evidence for anterograde axonal transport. J Neurosci 17:2295-2313. Medline

Cronk KM, Wilkinson GA, Grimes R, Wheeler EF, Jhaveri S, Fundin BT, Silos-Santiago I, Tessarollo L, Reichardt LF, Rice FL (2002) Diverse dependencies of developing Merkel innervation on the trkA and both fulllength and truncated isoforms of trkC. Development 129:3739-3750. Medline

Dassule HR, Lewis P, Bei M, Maas R, McMahon AP (2000) Sonic hedgehog regulates growth and morphogenesis of the tooth. Development 127: 4775-4785. Medline

Davis MI, Puhl HL 3rd (2011) Nr4al-eGFP is a marker of striosome-matrix architecture, development and activity in the extended striatum. PLoS One 6:e16619. CrossRef Medline

De Biasi S, Rustioni A (1988) Glutamate and substance P coexist in primary afferent terminals in the superficial laminae of spinal cord. Proc Natl Acad Sci U S A 85:7820-7824. CrossRef Medline

de Celis JF, Barrio R (2009) Regulation and function of Spalt proteins during animal development. Int J Dev Biol 53:1385-1398. CrossRef Medline

de Nooij JC, Doobar S, Jessell TM (2013) Etv1 inactivation reveals proprioceptor subclasses that reflect the level of NT3 expression in muscle targets. Neuron 77:1055-1068. CrossRef Medline

Drummond HA, Abboud FM, Welsh MJ (2000) Localizatino of beta and gamma subunits of $\mathrm{ENaC}$ in sensory nerve endings in the rat foot pad. Brain Res 884:1-12. CrossRef Medline

Ernfors P, Lee KF, Jaenisch R (1994) Mice lacking brain-derived neurotrophic factor develop with sensory deficits. Nature 368:147-150. CrossRef Medline

Ernsberger U (2009) Role of neurotrophin signalling in the differentiation of neurons from dorsal root ganglia and sympathetic ganglia. Cell Tissue Res 336:349-384. CrossRef Medline

Fujiyama T, Yamada M, Terao M, Terashima T, Hioki H, Inoue YU, Inoue T, Masuyama N, Obata K, Yanagawa Y, Kawaguchi Y, Nabeshima Y, Hoshino M (2009) Inhibitory and excitatory subtypes of cochlear nucleus neurons are defined by distinct bHLH transcription factors, Ptfla and Atoh1. Development 136:2049-2058. CrossRef Medline

Fundin BT, Silos-Santiago I, Ernfors P, Fagan AM, Aldskogius H, DeChiara TM, Phillips HS, Barbacid M, Yancopoulos GD, Rice FL (1997) Differential dependency of cutaneous mechanoreceptors on neurotrophins, trk receptors, and P75 LNGFR. Dev Biol 190:94-116. CrossRef Medline

Haeberle H, Fujiwara M, Chuang J, Medina MM, Panditrao MV, Bechstedt S, Howard J, Lumpkin EA (2004) Molecular profiling reveals synaptic release machinery in Merkel cells. Proc Natl Acad Sci U S A 101:1450314508. CrossRef Medline

Honda CN (1995) Differential distribution of calbindin-D28k and parvalbumin in somatic and visceral sensory neurons. Neuroscience 68:883892. CrossRef Medline

Horch KW, Whitehorn D, Burgess PR (1974) Impulse generation in type I cutaneous mechanoreceptors. J Neurophysiol 37:267-281. Medline

Hu MC, Mo R, Bhella S, Wilson CW, Chuang PT, Hui CC, Rosenblum ND (2006) GLI3-dependent transcriptional repression of Gli1, Gli2 and kidney patterning genes disrupts renal morphogenesis. Development 133: 569-578. CrossRef Medline
Hughes P, Dragunow M (1995) trkC may be an inducible transcription factor target gene. Neuroreport 6:465-468. CrossRef Medline

Ji SJ, Jaffrey SR (2012) Intra-axonal translation of SMAD1/5/8 mediates retrograde regulation of trigeminal ganglia subtype specification. Neuron 74:95-107. CrossRef Medline

Koltzenburg M, Stucky CL, Lewin GR (1997) Receptive properties of mouse sensory neurons innervating hairy skin. J Neurophysiol 78:1841-1850. Medline

Krimm RF, Davis BM, Woodbury CJ, Albers KM (2004) NT3 expressed in skin causes enhancement of SA1 sensory neurons that leads to postnatal enhancement of Merkel cells. J Comp Neurol 471:352-360. CrossRef Medline

Lawson JJ, McIlwrath SL, Woodbury CJ, Davis BM, Koerber HR (2008) TRPV1 unlike TRPV2 is restricted to a subset of mechanically insensitive cutaneous nociceptors responding to heat. J Pain 9:298-308. CrossRef Medline

LeMaster AM, Krimm RF, Davis BM, Noel T, Forbes ME, Johnson JE, Albers KM (1999) Overexpression of brain-derived neurotrophic factor enhances sensory innervation and selectively increases neuron number. J Neurosci 19:5919-5931. Medline

Li L, Rutlin M, Abraira VE, Cassidy C, Kus L, Gong S, Jankowski MP, Luo W, Heintz N, Koerber HR, Woodbury CJ, Ginty DD (2011) The functional organization of cutaneous low-threshold mechanosensory neurons. Cell 147:1615-1627. CrossRef Medline

Liebl DJ, Tessarollo L, Palko ME, Parada LF (1997) Absence of sensory neurons before target innervation in brain-derived neurotrophic factor-, neurotrophin 3-, and TrkC-deficient embryonic mice. J Neurosci 17: 9113-9121. Medline

Liebl DJ, Klesse LJ, Tessarollo L, Wohlman T, Parada LF (2000) Loss of brain-derived neurotrophic factor-dependent neural crest-derived sensory neurons in neurotrophin-4 mutant mice. Proc Natl Acad Sci U S A 97:2297-2302. CrossRef Medline

Luo W, Enomoto H, Rice FL, Milbrandt J, Ginty DD (2009) Molecular identification of rapidly adapting mechanoreceptors and their developmental dependence on Ret signaling. Neuron 64:841-856. CrossRef Medline

Luther JA, Birren SJ (2009) Neurotrophins and target interactions in the development and regulation of sympathetic neuron electrical and synaptic properties. Auton Neurosci 151:46-60. CrossRef Medline

Madisen L, Zwingman TA, Sunkin SM, Oh SW, Zariwala HA, Gu H, Ng LL, Palmiter RD, Hawrylycz MJ, Jones AR, Lein ES, Zeng H (2010) A robust and high-throughput Cre reporting and characterization system for the whole mouse brain. Nat Neurosci 13:133-140. CrossRef Medline

Maksimovic S, Nakatani M, Baba Y, Nelson AM, Marshall KL, Wellnitz SA, Firozi P, Woo SH, Ranade S, Patapoutian A, Lumpkin EA (2014) Epidermal Merkel cells are mechanosensory cells that tune mammalian touch receptors. Nature 509:617-621. CrossRef Medline

Maricich SM, Wellnitz SA, Nelson AM, Lesniak DR, Gerling GJ, Lumpkin EA, Zoghbi HY (2009) Merkel cells are essential for light-touch responses. Science 324:1580-1582. CrossRef Medline

Maricich SM, Morrison KM, Mathes EL, Brewer BM (2012) Rodents rely on Merkel cells for texture discrimination tasks. J Neurosci 32:3296-3300. CrossRef Medline

Marmigère F, Carroll P (2014) Neurotrophin signalling and transcription programmes interactions in the development of somatosensory neurons. Handb Exp Pharmacol 220:329-353. CrossRef Medline

Marmigère F, Ernfors P (2007) Specification and connectivity of neuronal subtypes in the sensory lineage. Nat Rev Neurosci 8:114-127. CrossRef Medline

McIlwrath SL, Lawson JJ, Anderson CE, Albers KM, Koerber HR (2007) Overexpression of neurotrophin-3 enhances the mechanical response properties of slowly adapting type 1 afferents and myelinated nociceptors. Eur J Neurosci 26:1801-1812. CrossRef Medline

Michael GJ, Averill S, Nitkunan A, Rattray M, Bennett DL, Yan Q, Priestley JV (1997) Nerve growth factor treatment increases brain-derived neurotrophic factor selectively in TrkA-expressing dorsal root ganglion cells and in their central terminations within the spinal cord. J Neurosci 17: 8476-8490. Medline

Minichiello L, Piehl F, Vazquez E, Schimmang T, Hökfelt T, Represa J, Klein R (1995) Differential effects of combined trk receptor mutations on dorsal root ganglion and inner ear sensory neurons. Development 121: 4067-4075. Medline

Nishida Y, Adati N, Ozawa R, Maeda A, Sakaki Y, Takeda T (2008) Identi- 
fication and classification of genes regulated by phosphatidylinositol 3-kinase- and TRKB-mediated signalling pathways during neuronal differentiation in two subtypes of the human neuroblastoma cell line $\mathrm{SH}$ SY5Y. BMC Res Notes 1:95. CrossRef Medline

Pasche F, Mérot Y, Carraux P, Saurat JH (1990) Relationship between Merkel cells and nerve endings during embryogenesis in the mouse epidermis. J Invest Derm 95:247-251. CrossRef Medline

Perez-Pinera P, García-Suarez O, Germanà A, Díaz-Esnal B, de Carlos F, Silos-Santiago I, del Valle ME, Cobo J, Vega JA (2008) Characterization of sensory deficits in TrkB knockout mice. Neurosci Lett 433:43-47. CrossRef Medline

Raouf R, Rugiero F, Kiesewetter H, Hatch R, Hummler E, Nassar MA, Wang F, Wood JN (2012) Sodium channels and mammalian sensory mechanotransduction. Mol Pain 8:21. CrossRef Medline

Reed-Geaghan EG, Maricich SM (2011) Peripheral somatosensation: a touch of genetics. Curr Opin Genet Dev 21:240-248. CrossRef Medline

Rios M, Fan G, Fekete C, Kelly J, Bates B, Kuehn R, Lechan RM, Jaenisch R (2001) Conditional deletion of brain-derived neurotrophic factor in the postnatal brain leads to obesity and hyperactivity. Mol Endocrinol 15: 1748-1757. CrossRef Medline

Shroyer NF, Helmrath MA, Wang VY, Antalffy B, Henning SJ, Zoghbi HY (2007) Intestine-specific ablation of mouse atonal homolog 1 (Math1) reveals a role in cellular homeostasis. Gastroenterology 132:2478-2488. CrossRef Medline

Stifani N (2014) Motor neurons and the generation of spinal motor neuron diversity. Front Cell Neurosci 8:293. CrossRef Medline

Szeder V, Grim M, Kucera J, Sieber-Blum M (2003) Neurotrophin-3 signal- ing in mammalian Merkel cell development. Dev Dyn 228:623-629. CrossRef Medline

Waldmann R, Champigny G, Bassilana F, Heurteaux C, Lazdunski M (1997) A proton-gated cation channel involved in acid-sensing. Nature 386:173177. CrossRef Medline

Wellnitz SA, Lesniak DR, Gerling GJ, Lumpkin EA (2010) The regularity of sustained firing reveals two populations of slowly adapting touch receptors in mouse hairy skin. J Neurophysiol 103:3378-3388. CrossRef Medline

Wende H, Lechner SG, Cheret C, Bourane S, Kolanczyk ME, Pattyn A, Reuter K, Munier FL, Carroll P, Lewin GR, Birchmeier C (2012) The transcription factor c-Maf controls touch receptor development and function. Science 335:1373-1376. CrossRef Medline

Williams JT, Christie MJ, Manzoni O (2001) Cellular and synaptic adaptations mediating opioid dependence. Physiol Rev 81:299-343. Medline

Woo SH, Ranade S, Weyer AD, Dubin AE, Baba Y, Qiu Z, Petrus M, Miyamoto T, Reddy K, Lumpkin EA, Stucky CL, Patapoutian A (2014) Piezo2 is required for Merkel-cell mechanotransduction. Nature 509:622-626. CrossRef Medline

Wright MC, Reed-Geaghan EG, Bolock AM, Fujiyama T, Hoshino M, Maricich SM (2015) Unipotent, Atoh1+ progenitors maintain the Merkel cell population in embryonic and adult mice. J Cell Biol 208:367-379. CrossRef Medline

Yuan JS, Reed A, Chen F, Stewart CN Jr (2006) Statistical analysis of realtime PCR data. BMC Bioinformatics 7:85. CrossRef Medline

Zhou XF, Rush RA (1996) Endogenous brain-derived neurotrophic factor is anterogradely transported in primary sensory neurons. Neuroscience 74 : 945-953. CrossRef Medline 